\title{
Simultaneous Observations of Nitrogen Dioxide, Formaldehyde and Ozone in the Indo-Gangetic Plain
}

\author{
Mriganka Sekhar Biswas ${ }^{1,2}$, Sachin D. Ghude ${ }^{1}$, Dinesh Gurnale ${ }^{1}$, Thara Prabhakaran ${ }^{1}$, \\ Anoop S. Mahajan ${ }^{*}$ \\ ${ }^{1}$ Indian Institute of Tropical Meteorology, Ministry of Earth Sciences, Pune 411008, India \\ ${ }^{2}$ Savitribai Phule Pune University, Pune 411007, India
}

\begin{abstract}
This study reports the concentrations of nitrogen dioxide $\left(\mathrm{NO}_{2}\right)$ and formaldehyde (HCHO), retrieved using the Multi AXis Differential Optical Absorption Spectroscopy (MAX-DOAS) technique and collocated observations of surface ozone $\left(\mathrm{O}_{3}\right)$ conducted over the Indo-Gangetic Plain (IGP) during the 2014 monsoon period as part of the Cloud Aerosol Interaction and Precipitation Enhancement Experiment (CAIPEEX). The average daytime $\mathrm{NO}_{2}$ mixing ratio was $0.81 \pm$ $0.20 \mathrm{ppbv}$ (parts per billion by volume) (range: $0.08-6.06 \mathrm{ppbv}$ ). $\mathrm{NO}_{2}$ was observed to decrease during the morning between 06:00 and 09:00 local time and then stabilise for the rest of the day. The average daytime HCHO mixing ratio was $1.93 \pm 0.60 \mathrm{ppbv}$ (range: $0.32-8.81 \mathrm{ppbv}$ ). Unlike $\mathrm{NO}_{2}, \mathrm{HCHO}$, driven by daytime photochemical formation from hydrocarbon precursors, increased during the early morning. The average $\mathrm{O}_{3}$ mixing ratio was $30.0 \pm 13.0$ ppbv (range: $2.7-81.9 \mathrm{ppbv}$ ) during the daytime and $22.5 \pm 10.2 \mathrm{ppbv}$ (range: $1-63 \mathrm{ppbv}$ ) during the nighttime. Analyses of the back trajectories indicatedfound that the $\mathrm{NO}_{2}$ mixing ratios during CAIPEEX-2014 were affected by long-range transport from thermal power plants situated about $110 \mathrm{~km}$ to the south but the $\mathrm{HCHO}$ mixing ratios and $\mathrm{O}_{3}$ production were influenced by local emissions. These observations suggest that in rural IGP, ozone concentrations are affected by local emission rather than by long-range transport.
\end{abstract}

Keywords: Nitrogen dioxide; Formaldehyde; Ozone; Indo-Gangetic Plain.

\section{INTRODUCTION}

Nitrogen dioxide $\left(\mathrm{NO}_{2}\right)$ is one of the most important trace gases in the atmosphere (Crutzen, 1979). Apart from being an atmospheric oxidant and pollutant (Burnett et al., 2004), it acts as a precursor for ozone $\left(\mathrm{O}_{3}\right)$ (Crutzen, 1970) and affects the hydroxyl radical $(\mathrm{OH})$ abundance through reactive photochemistry. As a pollutant, $\mathrm{NO}_{2}$ is associated with various health hazards (World Health Organization, 2013) and contributes towards acid rain and nitrate aerosol formation. It plays an indirect role in secondary aerosol formation (Chan et al., 2010) and locally contributes towards changes in radiative forcing (Solomon et al., 1999), hence indirectly affecting the climate system. Elevated tropospheric $\mathrm{NO}_{2}$ abundance usually coincides with other atmospheric pollutants, and hence, it can be used as a proxy for atmospheric pollution in general (Mayer, 1999; Molina and Molina, 2004). Major anthropogenic sources of $\mathrm{NO}_{2}$ include

\footnotetext{
* Corresponding author.

Tel.: +912025904526

E-mail address: anoop@tropmet.res.in
}

high temperature combustion of fossil fuels, biomass burning, industries, thermal power plants and automobiles. Forest fires, lightning and soil microbial processes are considered to be the main natural sources (Jaeglé et al., 2005). Formation of nitric acid $\left(\mathrm{HNO}_{3}\right)$ during the daytime and dinitrogen pentoxide $\left(\mathrm{N}_{2} \mathrm{O}_{5}\right)$ hydrolysis during night along with dry deposition and transport are the dominant sinks of tropospheric nitrogen oxides $\left(\mathrm{NO}_{\mathrm{x}}\right)$ (Finlayson-Pitts and Pitts, 2000; Jacob, 2000). Understanding of current emissions (Martin et al., 2006), the performance of chemical transport models (Zyrichidou et al., 2009; Huijnen et al., 2010, and references therein) and changes in anthropogenic emissions (Stavrakou et al., 2008; Wang et al., 2012) have been studied using satellite retrieved $\mathrm{NO}_{2}$ columns. Observations of $\mathrm{NO}_{2}$ (Johansson et al., 2009; Wagner et al., 2010; Constantin et al., 2013) using the Differential Optical Absorption Spectroscopy (DOAS) technique (Noxon, 1975; Solomon et al., 1987) have been reported at various locations around the world and in several cases have been used for retrieving vertical profiles of atmospheric $\mathrm{NO}_{2}$ and also for validating satellite observations (Hönninger et al., 2004; Frieß et al., 2006; Wagner et al., 2011; Hendrick et al., 2014).

Formaldehyde (HCHO) is the most abundant and smallest 
carbonyl compound observed in the troposphere (Hak et al., 2005, and references therein). It is an intermediate oxidation product of various volatile organic compounds (VOCs). HCHO has biogenic (e.g., vegetation), pyrogenic (mainly biomass burning) and anthropogenic (e.g., industrial emissions and automobiles) sources (Carlier et al., 1986; Lee et al., 1997; Fu et al., 2007; Hak et al., 2005; Herndon et al., 2005; Smedt et al., 2010). The background levels of $\mathrm{HCHO}$ are mainly sustained by oxidation of long-lived VOCs, such as methane, whereas the spatial variability of $\mathrm{HCHO}$ is primarily associated with the oxidation of shorter lived, reactive non-methane VOCs of biogenic (e.g., isoprene) or anthropogenic (e.g., butane) origin. Being an oxidation product, $\mathrm{HCHO}$ is a useful indicator of biogenic and anthropogenic emissions of hydrocarbons (Andreae and Merlet, 2001; Geiger et al., 2002; Seco et al., 2007; Stavrakou et al., 2009; Barkley et al., 2013; Stavrakou et al., 2014). Photolysis and oxidation by $\mathrm{OH}$ radicals, yielding hydroperoxyl radicals $\left(\mathrm{HO}_{2}\right)$ and carbon monoxide $(\mathrm{CO})$ (hence affecting the global $\mathrm{CO}$ budget and the oxidative capacity of the atmosphere), is the main removal process for atmospheric HCHO. Dry and wet depositions are the other important removal processes of HCHO (Atkinson, 2000). Being a crucial participant in tropospheric $\mathrm{O}_{3}$ formation (thereby affecting air quality), the monitoring of the spatial and temporal variability of HCHO is essential (Abbot, 2003; De Smedt et al., 2008). Satellite observations of tropospheric HCHO columns have been successfully reported for over two decades (Chance et al., 2000; Palmer et al., 2001; Wittrock et al., 2006; De Smedt et al., 2008). These observations have helped us study the spatial and temporal trends and to estimate the emissions of VOCs (Gonzi et al., 2011; Barkley et al., 2013). Higher concentrations of $\mathrm{HCHO}$ associated with areas of dense vegetation and biomass burning indicate that on a global scale, the major sources are of biogenic origin (Vrekoussis et al., 2010).

$\mathrm{O}_{3}$ plays an important role in atmospheric chemistry (Crutzen, 1974, 1970; Logan et al., 1981; Barrie et al., 1988). Surface $\mathrm{O}_{3}$ is a major pollutant and a greenhouse gas affecting the global radiation budget (IPCC, 2007). In the troposphere, $\mathrm{O}_{3}$ acts as a secondary pollutant formed in the presence of sunlight and its precursors, e.g., $\mathrm{NO}_{\mathrm{x}}$ or VOCs (Fishman and Crutzen, 1978). Stratospheric subsidence is another source of tropospheric ozone (Holton et al., 1995). Ozone participates in the formation of $\mathrm{OH}$, thus affecting the oxidising capacity of the atmosphere. Increased levels of tropospheric ozone have an adverse effect on human health (Desqueyroux et al., 2002) and crop yield (Morgan et al., 2006; Ghude et al., 2014). Increased anthropogenic emissions from fossil fuel combustion in power plants, large-scale industries and automobiles have led to an increase in the surface $\mathrm{O}_{3}$ concentrations over the past few decades (Sillman and Samson, 1995; Peleg et al., 1997; Ryerson et al., 2001). Solar radiation and higher water vapour content in the atmosphere, along with increased $\mathrm{NO}_{\mathrm{x}}$ and VOC concentrations, lead to higher photochemical production of $\mathrm{O}_{3}$ in the tropical regions (Crutzen, 1970; Andreae and Crutzen, 1997; Sánchez et al., 2005). $\mathrm{NO}_{2}$ participates as a catalyst and, in the presence of solar radiation, photochemically dissociates to form $\mathrm{NO}$ (nitrogen oxide) and $\mathrm{O}\left({ }^{3} \mathrm{P}\right)$.

$\mathrm{NO}_{2}+h v \rightarrow \mathrm{NO}+\mathrm{O}\left({ }^{3} \mathrm{P}\right)$

The resultant oxygen atom then reacts with molecular oxygen to form $\mathrm{O}_{3}$. NO reacts with the $\mathrm{HO}_{2}$ radical and converts back into $\mathrm{NO}_{2}$, which continues the catalytic $\mathrm{O}_{3}$ production process.

$\mathrm{O}\left({ }^{3} \mathrm{P}\right)+\mathrm{O}_{2}+\mathrm{M} \rightarrow \mathrm{O}_{3}+\mathrm{M}$

$\mathrm{HO}_{2}+\mathrm{NO} \rightarrow \mathrm{NO}_{2}+\mathrm{OH}$

$\mathrm{O}_{3}$ also photolyses at wavelengths $<310 \mathrm{~nm}$ to form $\mathrm{O}\left({ }^{1} \mathrm{D}\right)$, which then reacts with water vapour to yield $\mathrm{OH}$ radicals.

$\mathrm{O}_{3}+h v \rightarrow \mathrm{O}\left({ }^{1} \mathrm{D}\right)+\mathrm{O}_{2}$

$\mathrm{O}\left({ }^{1} \mathrm{D}\right)+\mathrm{H}_{2} \mathrm{O} \rightarrow 2 \mathrm{OH}$

The oxidation of methane (and other NMVOCs) by $\mathrm{OH}$ radical forms $\mathrm{HO}_{2}$ and $\mathrm{HCHO}$ (higher aldehydes in the case of NMVOC oxidation). Further photochemical oxidation of formaldehyde with $\mathrm{OH}$ radicals also results in the formation of $\mathrm{HO}_{2}$ (R10)-(R12).

$$
\begin{aligned}
& \mathrm{OH}+\mathrm{CH}_{4} \rightarrow \mathrm{CH}_{3}+\mathrm{H}_{2} \mathrm{O} \\
& \mathrm{CH}_{3}+\mathrm{O}_{2}+\mathrm{M} \rightarrow \mathrm{CH}_{3} \mathrm{O}_{2}+\mathrm{M} \\
& \mathrm{CH}_{3} \mathrm{O}_{2}+\mathrm{NO} \rightarrow \mathrm{CH}_{3} \mathrm{O}+\mathrm{NO}_{2} \\
& \mathrm{CH}_{3} \mathrm{O}+\mathrm{O}_{2} \rightarrow \mathrm{HCHO}+\mathrm{HO}_{2} \\
& \mathrm{HCHO}+h v \rightarrow \mathrm{H}+\mathrm{HCO} \\
& \mathrm{HCHO}+\mathrm{OH} \rightarrow \mathrm{H}_{2} \mathrm{O}+\mathrm{HCO} \\
& \mathrm{HCHO}+\mathrm{OH} \rightarrow \mathrm{H}_{2} \mathrm{O}+\mathrm{HCO} \\
& \mathrm{HCO}+\mathrm{O}_{2} \rightarrow \mathrm{CO}+\mathrm{HO}_{2}
\end{aligned}
$$

At night, in the absence of sunlight, $\mathrm{O}_{3}$ reacts with $\mathrm{NO}_{2}$ to form the nitrate radical $\left(\mathrm{NO}_{3}\right)$, which can eventually lead to the removal of $\mathrm{NO}_{\mathrm{x}}$ from the atmosphere, as mentioned earlier.

$\mathrm{O}_{3}+\mathrm{NO}_{2} \rightarrow \mathrm{NO}_{3}$

The Indo-Gangetic Plain (IGP) region covers $\sim 21 \%$ of the Indian subcontinent land area, accommodating $40 \%$ of the Indian population (Nair et al., 2007). Coal-based thermal power plants (Prasad et al., 2006), coal-based small and medium industries, biomass burning and bio-fuel burning for domestic cooking (Reddy and Venkataraman, 2002) are the main sources for atmospheric pollutants in the IGP. Precise knowledge of $\mathrm{NO}_{2}, \mathrm{HCHO}$ and $\mathrm{O}_{3}$ sources and the 
monitoring of their abundance are very important for determining their exact role in atmospheric chemistry on a local, regional and global scale. Recent studies over India have studied the inter-annual variation of $\mathrm{NO}_{2}$ and $\mathrm{HCHO}$ using several years of satellite based data (De Smedt et al., 2008; Smedt et al., 2010; Ghude et al., 2013; Hilboll et al., 2013; Mahajan et al., 2015). However, scant information from ground based instruments is available in India to validate the satellite observations (Pandey et al., 1992; Sharma et al., 2010; Mandal et al., 2012; Reddy et al., 2012). Ground based observations of HCHO in India are rare (Khare et al., 1997a, b; Dutta et al., 2010), and further satellite validation is necessary, especially considering a model-satellite discrepancy (Mahajan et al., 2015). In a recent study, MAX-DOAS observations of $\mathrm{NO}_{2}$ and $\mathrm{HCHO}$ have been reported from the IGP region (Pantnagar; $29.03^{\circ} \mathrm{N}$, $79.47^{\circ} \mathrm{E}$ ) for the year 2017 (Hoque et al., 2018). The HCHO mixing ratios were found to be in the range of 2-4 ppbv for July and August 2017 and of 4-6 ppbv for September 2017. The $\mathrm{NO}_{2}$ mixing ratios were found to be between 0.5 and 1 ppbv for July and August 2017 and less than 0.5 ppbv in September 2017. Various groups have conducted studies over India and reported elevated levels of $\mathrm{O}_{3}$ during late autumn and winter, extending through May (Lal et al., 2000; Nair et al., 2002; Naja and Lal, 2002; Jain et al., 2005; Beig et al., 2007; Mittal et al., 2007; Ghude et al., 2008). Low altitude rural sites in India show maximum $\mathrm{O}_{3}$ concentrations during summer and winter and minimum concentrations during the Asian Summer Monsoon (ASM) season (Debaje and Kakade, 2006; Reddy et al., 2011). In another recent study, decadal changes of surface ozone were reported over $\sim 40$ years (1973-2014) from Thiruvananthapuram $\left(8.542^{\circ} \mathrm{N}\right.$, $76.858^{\circ} \mathrm{E}$ ) in peninsular India (Nair et al., 2018). The ozone mixing ratios were found in the range of 10-20 ppbv for the months of July, August and September over the 40 years of observations.

In this study, we report the retrieval of $\mathrm{NO}_{2}$ and $\mathrm{HCHO}$ using the Multi axis Differential Optical Absorption Spectroscopy (MAX-DOAS) technique along with surface $\mathrm{O}_{3}$ observations carried out during the Cloud Aerosol Interaction and Precipitation Enhancement Experiment (CAIPEEX-2014). We also investigate the effect of longrange transport of $\mathrm{O}_{3}$ precursors and ascertain the main drivers of $\mathrm{O}_{3}$ over a rural site in the IGP.

\section{MEASUREMENT SITE AND METHODS}

\section{Measurement Site}

The CAIPEEX-2014 campaign was carried out on the Rajiv Gandhi South Campus of Banaras Hindu University in Barkachha, Mirzapur District, Uttar Pradesh, $169 \mathrm{~m}$ above mean sea level $\left(25.06^{\circ} \mathrm{N}, 82.59^{\circ} \mathrm{E}\right.$; Fig. 1$)$. The site represents a rural location in the IGP, with extensive grasslands and cropland surrounding the measurement location. The site is approximately $300 \mathrm{~km}$ south of the Himalayan range. It is located $47 \mathrm{~km}$ south-west of the city of Varanasi and $8 \mathrm{~km}$ south of Mirzapur. Farther to the south, there are two large thermal power plants $\sim 110 \mathrm{~km}$ from the site: Vindhyachal Thermal Power Station and Rihand Thermal Power Station (Fig. 1). A state highway passes through the university campus about $\sim 100 \mathrm{~m}$ from the observation site on the western side. Towards the south, at a distance of $\sim 750 \mathrm{~m}$, is a marketplace, which attracts traffic during the daytime. The Majhawati River

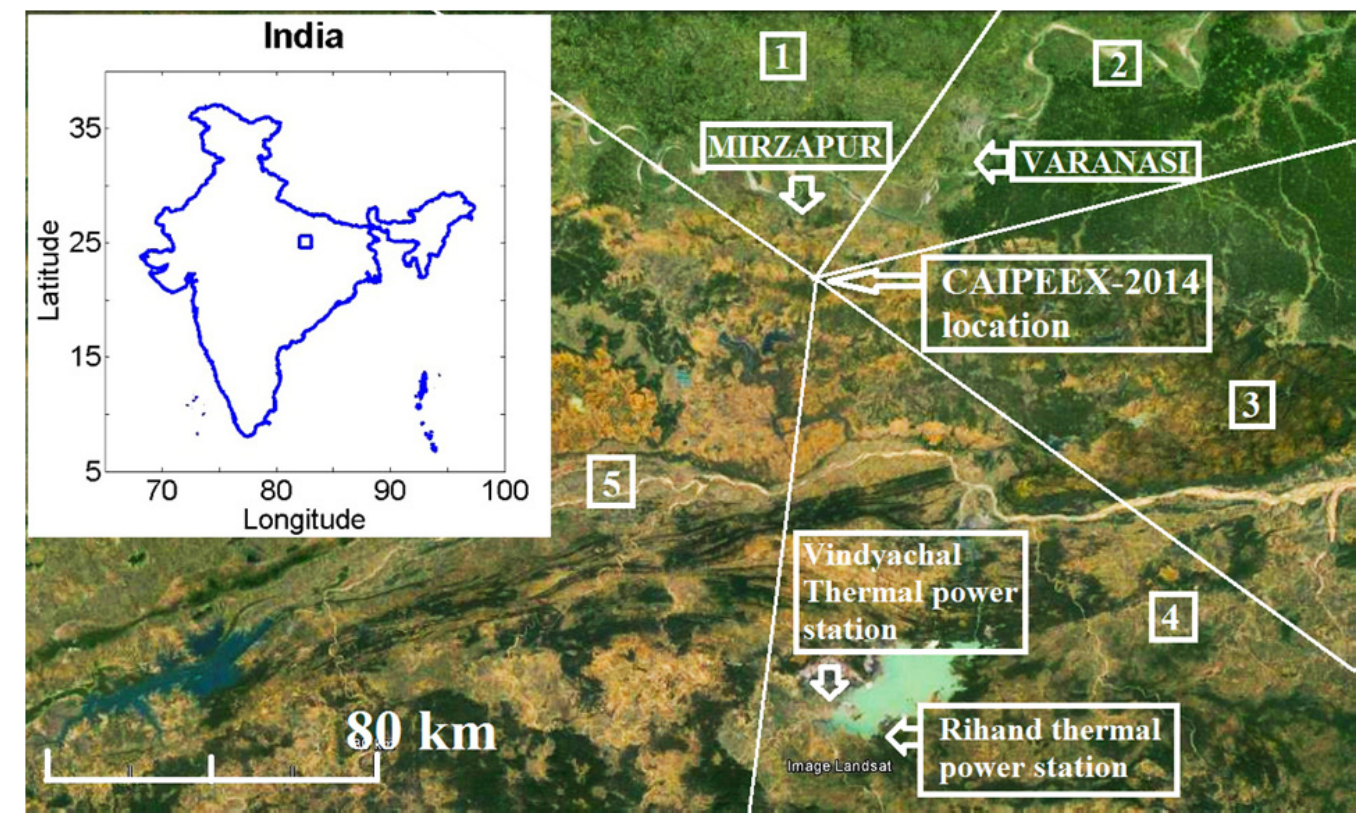

Fig. 1. CAIPEEX-2014 location with nearby cities and thermal power plants indicated. The area around the measurement site was divided into five sectors. Sectors 1 and 2 represent the nearby town of Mirzapur (which, at a distance of $10 \mathrm{~km}$, is closest to the measurement site) and the city of Varanasi (at a distance of $60 \mathrm{~km}$ ). Sector 3 represents a vegetated area to the east of the measurement site. Sector 4 represents the region with the two thermal power plants, and Sector 5 represents the rural IGP region. 
flows on the eastern side of the measurement location. The climate in this region is predominantly dry (sub-tropical to dry). The winter season is short (December-February), and the summer (March-June) is followed by the monsoon (July-September) and a brief autumn (October-November). The temperature peaks at $\sim 48^{\circ} \mathrm{C}$ during the summer and drops to a low of $\sim 4^{\circ} \mathrm{C}$ during December and January. The average annual rainfall at the site is $1059 \mathrm{~mm}$, of which $90 \%$ is received during the ASM period. The onset of ASM in this region is usually during the third to fourth week in June and lasts up to the end of September. Meteorological parameters were measured (using an all in one weather sensor for temperature, $\mathrm{RH}$ and winds) and a Kipp and Zonen CNR4 net radiometer for radiation for the period of 23 July 2014 to 20 September 2014, with a data gap during 15 August 2014 to 23 August 2014 due to instrumental problems (Fig. 3).

\section{Ozone Measurements}

$\mathrm{An}_{3}$ analyser (EC9810; Ecotech) was used for surface $\mathrm{O}_{3}$ measurements. It is a non-dispersive ultraviolet photometer, which alternately switches between a selective ozone scrubber in and out of the measuring stream and computes the ratio of transmitted light, giving a measure of ozone concentration. The lower detection limit is $0.5 \mathrm{ppbv}$ (equivalent to $\mathrm{nmol} \mathrm{mol}{ }^{-1}$ ) or $0.2 \%$ of the concentration reading, whichever is greater, and the instrument has a precision of $1 \mathrm{ppbv}$ or $1 \%$ of the reading, whichever is greater. The instrument was active from 23 July 2014 to 7 Jan 2015. There was no significant data gap aside from power failures at the station, which lasted for short periods.

\section{MAX-DOAS Instrumental Setup}

MAX-DOAS is a passive DOAS technique where scattered sunlight along multiple viewing directions are analysed and combined to get the distribution of various trace gases. As the differential absorption patterns of individual absorbers are unique, simultaneous measurements of different absorbers can be made, provided that the cross-interference from other absorbers and contribution from broadband scattering is eliminated. MAX-DOAS measurements at lower elevation angles are more sensitive towards lower tropospheric trace gas layers, as the photons travel longer paths through the lower troposphere compared to higher elevation angles. The MAX-DOAS instrument (Envimes) used for this campaign has two ultra-low stray light $75 \mathrm{~mm}$ Avantes spectrometers. The first spectrometer covers a range of $306.08-468.77 \mathrm{~nm}$, and the second spectrometer operates in the range of 441.91-583.36 nm. Both the spectrometers have a full width, half maximum resolution of $0.6 \mathrm{~nm}$ and a $100 \mu \mathrm{m}$ slit. The spectrometers are temperature stabilised (maintained at an average temperature of $20^{\circ} \mathrm{C}$ ) with a deviation of $<0.05^{\circ} \mathrm{C}$.

The MAX-DOAS instrument was installed on the rooftop of a water tower at the campaign site, at a height of $\sim 10 \mathrm{~m}$ above ground level. The scanner unit pointed towards the geometric north, with a clear line of sight to the horizon. Spectra were recorded between 23 July 2014 to 20 September 2014, with a gap during 1-2 August 2014 and 17-25 August 2014 due to instrumental issues. Each full scan measured scattered sunlight along 10 different elevation angles $\left(90^{\circ}, 40^{\circ}, 20^{\circ}, 10^{\circ}, 7^{\circ}, 5^{\circ}, 3^{\circ}, 2^{\circ}, 1^{\circ}\right.$ and $0.5^{\circ}$ ) when the solar zenith angle (SZA) was $<80^{\circ}$. For $80^{\circ}<\mathrm{SZA}<97^{\circ}$, sunlight spectra were measured only in the zenith direction. The exposure time per individual spectrum was calculated according to $70 \%$ saturation of the charged coupled device (CCD) sensor. The total exposure per elevation angle was set to 60 seconds. The dark current, offset and calibration spectra were recorded at the end of every day and were used to correct the measured spectra. Nonlinearity of the spectrometers was also taken into account. All the results from the campaign are presented in local time (Indian Standard Time).

\section{DOAS Analysis Settings}

The measured spectra were pre-processed with Matlab ${ }^{\circledR}$ for dark current and offset correction and then analysed using the QDOAS spectral fitting software (Danckaert, 2014). Zenith spectra from each scan was taken as a reference to remove the stratospheric contribution in offaxis measurements (Hönninger et al., 2004).

HCHO differential slant column densities (DSCDs) were retrieved in the $332-358 \mathrm{~nm}$ wavelength window. Although $\mathrm{HCHO}$ shows characteristic absorption in the ultraviolet spectral region of $240-320 \mathrm{~nm}$, the abovementioned wavelength range was chosen to avoid interference from strong ozone absorption bands below $320 \mathrm{~nm}$. For $\mathrm{O}_{4}$ and $\mathrm{NO}_{2}$, the 350-386 nm and 433-460 nm intervals were chosen. The details of the cross-sections used in QDOAS retrieval are mentioned in Table 1. For all three fitting windows, a third-order polynomial and an offset with a zero order polynomial was also fitted. A ring spectrum (Grainger and Ring, 1962) was fitted (Chance and Kurucz, $2010,250^{\circ} \mathrm{K}$ ) in addition to the fourth power ring spectrum following Wagner et al. (2009). Examples of the fits for $\mathrm{O}_{4}, \mathrm{NO}_{2}$ and $\mathrm{HCHO}$ are shown in Fig. 2.

Boundary layer volume mixing ratios (vmr) for $\mathrm{NO}_{2}$ and $\mathrm{HCHO}$ were retrieved from the DSCDs using the $\mathrm{O}_{4}$ DSCDs. DSCDs from elevation angles $<3^{\circ}$ were used, as the DSCDs from higher elevation angles contain information from the free troposphere. Only scans with SZA $<60^{\circ}$ were taken into account. Standard atmospheric temperature, pressure and $\mathrm{O}_{4}$ concentration profiles were used for the calculation of the path length. The trace gas mixing ratios were then calculated over the path towards the north per the methodology used by other groups in the past (Sinreich et al., 2010; Mahajan et al., 2012; Gómez Martín et al., 2013; Prados-Roman et al., 2015).

\section{RESULTS AND DISCUSSIONS}

\section{Meteorology}

Fig. 3 shows the time series for various meteorological parameters measured during the campaign. The left column shows the temperature, relative humidity and wind speed (top to bottom), and the right column shows the atmospheric pressure, incoming solar radiation and wind direction (top to bottom). There was a gap in the data from the late 
Table 1. MAX-DOAS retrieval settings for the different species retrieved during the campaign.

\begin{tabular}{|c|c|c|}
\hline $\mathrm{HCHO}$ & $\mathrm{O}_{4}$ & $\mathrm{NO}_{2}$ \\
\hline \multicolumn{3}{|l|}{ Fitting interval } \\
\hline $332-358 \mathrm{~nm}$ & $350-386 \mathrm{~nm}$ & $433-460 \mathrm{~nm}$ \\
\hline \multicolumn{3}{|l|}{ Cross-sections used } \\
\hline $\begin{array}{l}\text { HCHO: Meller and Moortgat } \\
(2000), 298^{\circ} \mathrm{K}\end{array}$ & $\mathrm{O}_{4}$ : Greenblatt et al. (1990), $296^{\circ} \mathrm{K}$ & $\begin{array}{l}\mathrm{NO}_{2} \text { : Vandaele et al. (1998), } 294^{\circ} \mathrm{K} \\
\text { and } 220^{\circ} \mathrm{K}\end{array}$ \\
\hline $\begin{array}{l}\mathrm{O}_{3} \text { : Bogumil et al. (2003), } 223^{\circ} \mathrm{K} \\
\text { and } 293^{\circ} \mathrm{K}\end{array}$ & $\begin{array}{l}\mathrm{NO}_{2} \text { : Vandaele } \text { et al. }(1998), 294^{\circ} \mathrm{K} \\
\text { and } 220^{\circ} \mathrm{K}\end{array}$ & $\begin{array}{l}\mathrm{O}_{3} \text { : Bogumil et al. }(2003), 223^{\circ} \mathrm{K} \text { and } \\
293^{\circ} \mathrm{K}\end{array}$ \\
\hline $\mathrm{O}_{4}$ : Greenblatt et al. (1990), $296^{\circ} \mathrm{K}$ & $\begin{array}{l}\text { HCHO: Meller and Moortgat (2000), } \\
298^{\circ} \mathrm{K}\end{array}$ & CHOCHO: Volkamer (2005), $296^{\circ} \mathrm{K}$ \\
\hline $\mathrm{NO}_{2}$ : Vandaele et al. (1998), $294^{\circ} \mathrm{K}$ & $\begin{array}{l}\mathrm{O}_{3} \text { : Bogumil et al. }(2003), 223^{\circ} \mathrm{K} \text { and } \\
293^{\circ} \mathrm{K}\end{array}$ & $\mathrm{O}_{4}$ : Greenblatt et al. (1990), $296^{\circ} \mathrm{K}$ \\
\hline HONO: Stutz et al. (2000), $298^{\circ} \mathrm{K}$ & HONO: Stutz et al. (2000), $298^{\circ} \mathrm{K}$ & $\mathrm{H}_{2} \mathrm{O}: \operatorname{Hitran}(2009), 296^{\circ} \mathrm{K}$ \\
\hline Ring spectra & & \\
\hline
\end{tabular}

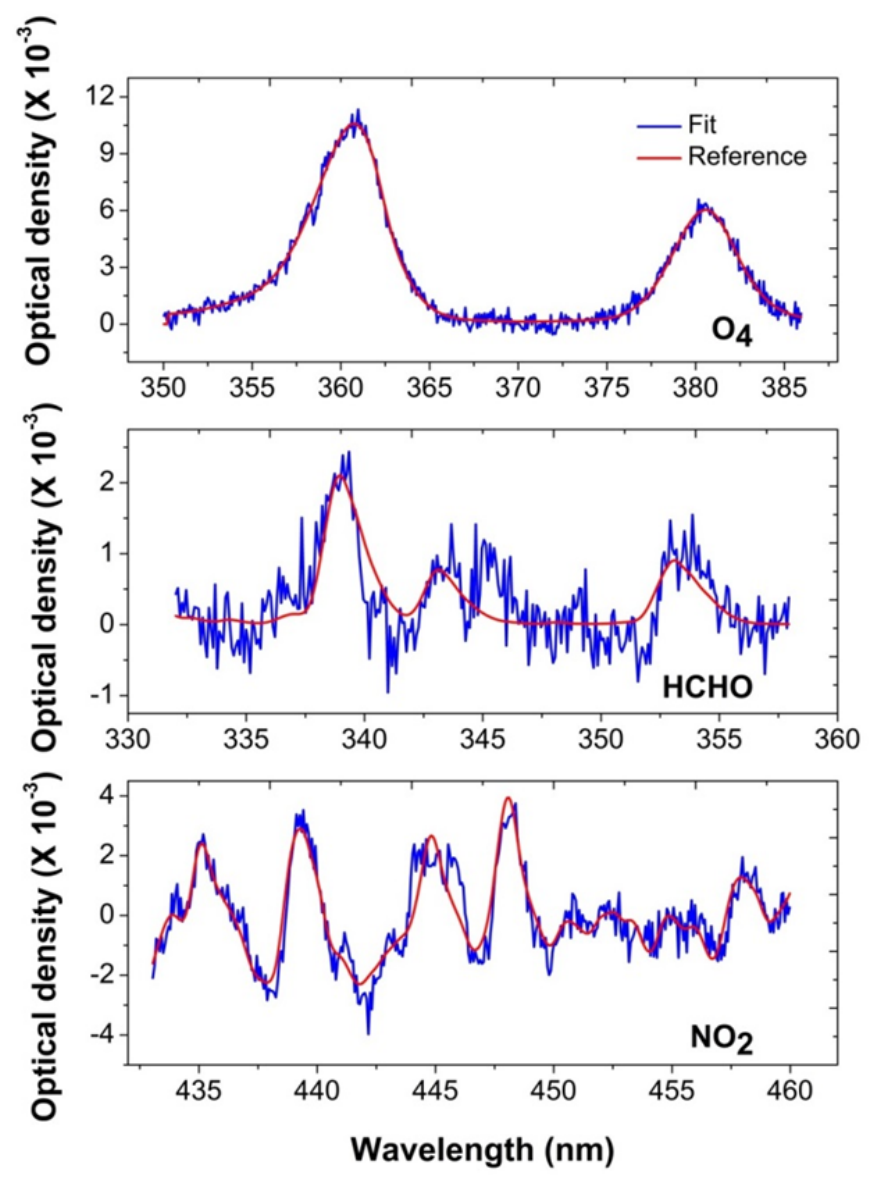

Fig. 2. DOAS fit for $\mathrm{O}_{4}, \mathrm{NO}_{2}$ and $\mathrm{HCHO}$. Top panel: $\mathrm{O}_{4} ; 30$ August 2014, 08:03:43; $\mathrm{SZA}=58.4^{\circ}$; elevation angle $=10.0^{\circ}$; $\mathrm{DSCD}=2.32 \times 10^{43}$ molecules $^{2} \mathrm{~cm}^{-5} ; \mathrm{RMS}=3.4 \times 10^{-4}$. Middle panel: HCHO; 30 August 2014, 08:27:38; SZA = 52.9 ; elevation angle $=3.0^{\circ} ; \mathrm{DSCD}=4.08 \times 10^{16}$ molecules $\mathrm{cm}^{-2} ; \mathrm{RMS}=4.0 \times 10^{-4}$. Bottom panel: $\mathrm{NO}_{2} ; 30$ August 2014, 08:09:56; $\mathrm{SZA}=56.9^{\circ}$; elevation angle $=0.5^{\circ} ; \mathrm{DSCD}=1.53 \times 10^{16}$ molecules $\mathrm{cm}^{-2} ; \mathrm{RMS}=5.9 \times 10^{-4}$.

afternoon of 14 August to the morning of 24 August due to instrumental issues. The average atmospheric temperature was $28.6^{\circ} \mathrm{C}$ with a minimum and maximum temperature of $24^{\circ} \mathrm{C}$ and $36.7^{\circ} \mathrm{C}$, respectively. The average atmospheric pressure was $982.6 \mathrm{hPa}$ with a minimum and maximum pressure of $973.6 \mathrm{hPa}$ and $987.6 \mathrm{hPa}$, respectively. The average relative humidity was $78.2 \%$ with a minimum and maximum relative humidity of $39.4 \%$ and $94.5 \%$, 

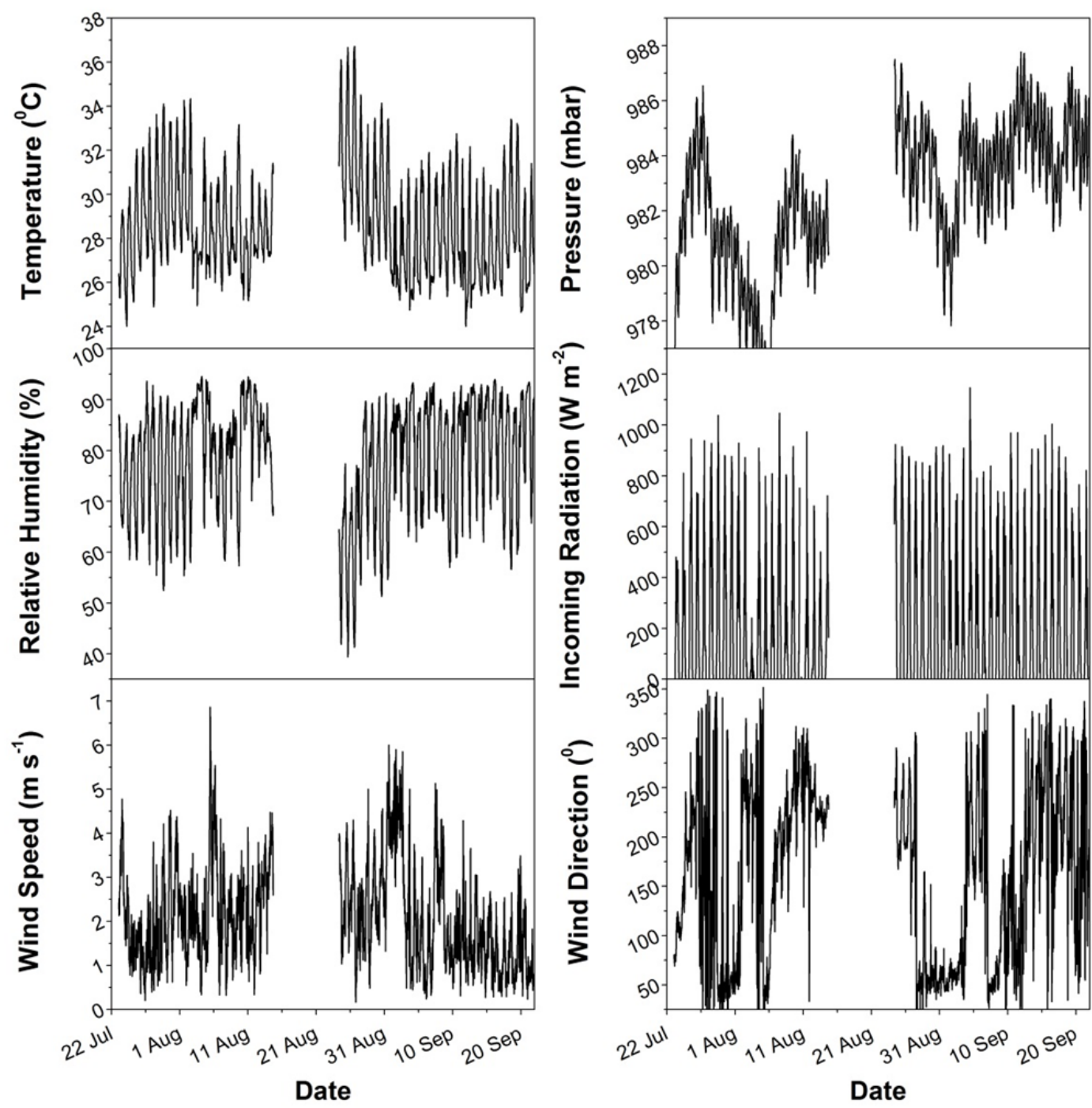

Fig. 3. Time series of various meteorological parameters measured during CAIPEEX-2014. The left column represents temperature, relative humidity and wind speed from top to bottom. The right column represents air pressure, incoming solar radiation and wind direction from top to bottom.

respectively. The average incoming solar radiation was 192.2 $\mathrm{Wm}^{-2}$. There were several cloud free days, and even on days with clouds, several cloud free hours were recognised using the spectrometer data along with a sky imager, and these data were used to retrieve mixing ratios from the DOAS analysis. The average wind speed was $2.1 \mathrm{~m} \mathrm{~s}^{-1}$ with a minimum and maximum wind speed of $0.17 \mathrm{~m} \mathrm{~s}^{-1}$ and $6.86 \mathrm{~m} \mathrm{~s}^{-1}$.

$\boldsymbol{O}_{4}$

$\mathrm{O}_{4}$ DSCDs were found to be higher at lower elevation angles, as expected. This is due to the fact that the intensity of $\mathrm{O}_{4}$ absorption is proportional to the square of the oxygen pressure. At lower elevation angles, photons travel longer paths in the lower troposphere and interact more with tropospheric absorbing species before reaching the instrument. There is a decrease in the $\mathrm{O}_{4}$ DSCD at the lowest three angles $\left(2^{\circ}, 1^{\circ}\right.$ and $\left.0.5^{\circ}\right)$, indicating the presence of aerosols in the boundary layer. This is in accordance with the fact that the campaign happened during the ASM season. The average RMS and detection limit for $\mathrm{O}_{4}$ DSCDs were $7 \times 10^{-4}$ and $3.1 \times 10^{42}$ molecules ${ }^{2} \mathrm{~cm}^{-5}$, respectively, at the $1^{\circ}$ elevation angle. The average $\mathrm{O}_{4}$ DSCD at a $1^{\circ}$ elevation angle was $1.4 \times 10^{43}$ molecules ${ }^{2} \mathrm{~cm}^{-5}$ with a maximum DSCD of $2.5 \times 10^{43}$ molecules ${ }^{2} \mathrm{~cm}^{-5}$ (Fig. 4). The $\mathrm{O}_{4}$ DSCDs were then used to estimate the path length and hence the trace gas mixing ratios, as described earlier.

$\mathrm{NO}_{2}$

$\mathrm{NO}_{2}$ DSCDs were also found to be higher at lower elevation angles (Fig. 4). This, in conjunction with the $\mathrm{O}_{4}$ DSCDs, indicates that most of the $\mathrm{NO}_{2}$ is present close to the surface with a decreasing gradient with altitude. For the three lowest elevation angles, the DSCDs do not increase with a decrease in elevation angle, which can be attributed to the presence of aerosols in the boundary layer, as indicated by the decreasing $\mathrm{O}_{4}$ DSCDs. The average RMS and detection limit for $\mathrm{NO}_{2}$ DSCDs were $6 \times 10^{-4}$ 


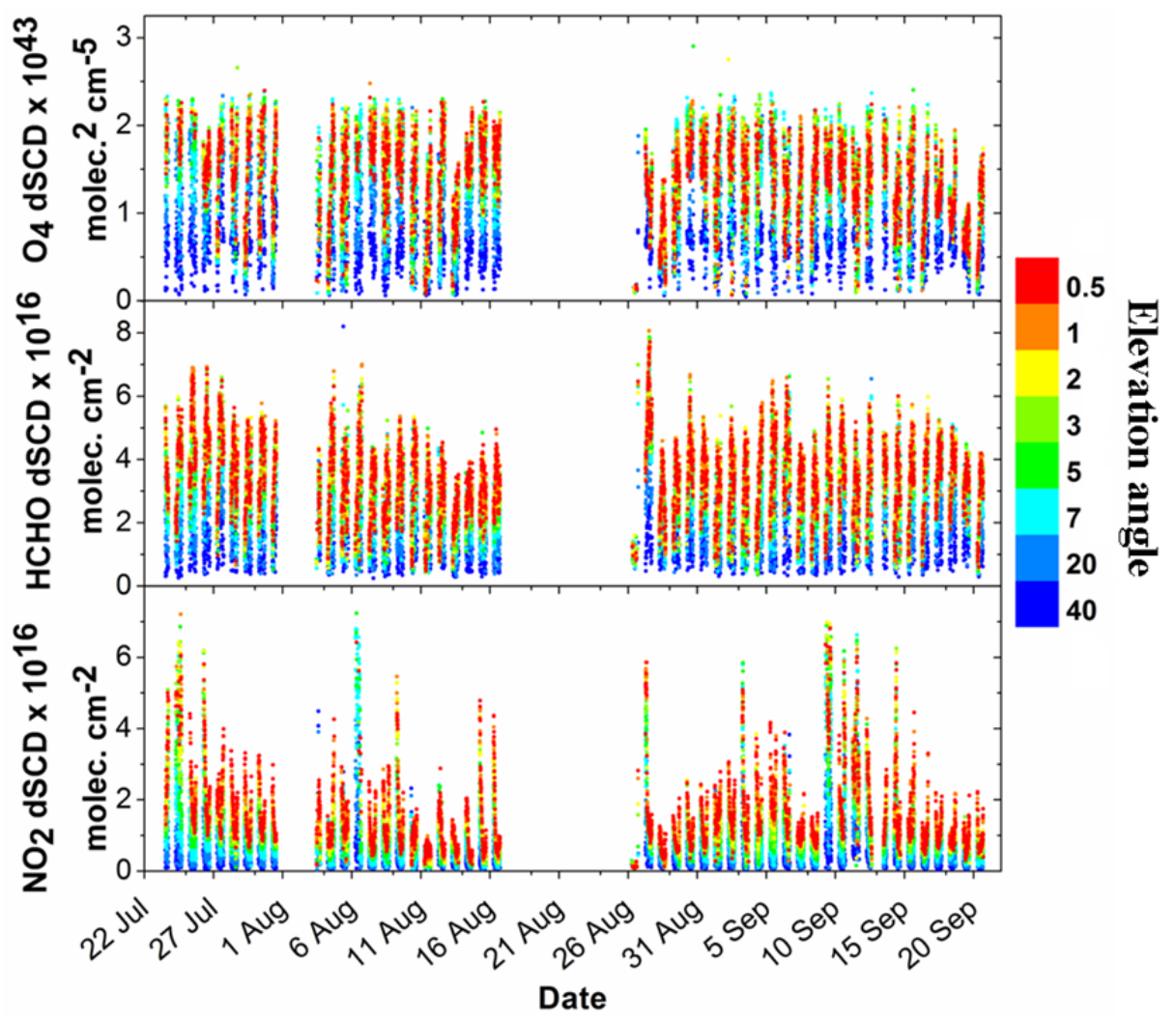

Fig. 4. Slant column densities of $\mathrm{O}_{4}, \mathrm{HCHO}$ and $\mathrm{NO}_{2}$ from CAIPEEX-2014 campaign. Different colours represent measurements at different viewing elevation angles.

and $3 \times 10^{15}$ molecules $\mathrm{cm}^{-2}$ at the $1^{\circ}$ elevation angle. The average $\mathrm{NO}_{2}$ DSCD at the $1^{\circ}$ elevation angle was $1.5 \times$ $10^{16}$ molecules $\mathrm{cm}^{-2}$, with a maximum DSCD of $7.2 \times 10^{16}$ molecules $\mathrm{cm}^{-2}$ (Fig. 4, bottom panel).

Using the method described earlier, $\mathrm{NO}_{2}$ mixing ratios were estimated for elevation angels $<3^{\circ}$ to get the contribution to $\mathrm{NO}_{2}$ within the boundary layer near the surface (e.g., Wagner et al., 2004). The resulting time series for $\mathrm{NO}_{2}$ is shown in Fig. 5. The average $\mathrm{NO}_{2}$ mixing ratio was $0.81 \pm 0.20 \mathrm{ppbv}$ (range: $0.08-6.06 \mathrm{ppbv}$ ). The average detection limit for $\mathrm{NO}_{2}$ was 0.16 ppbv. $\mathrm{NO}_{2}$ mixing ratios decreased from an early morning high until mid-day and increased again later in the day (Fig. 6). This can be attributed to the daytime photochemical decomposition of $\mathrm{NO}_{2}$ by solar radiation as discussed in the introduction (R1).

The average vertical column densities (VCDs) for $\mathrm{NO}_{2}$, as observed by the satellite-based ozone monitoring instrument (OMI), were studied to understand the spatial distribution over the IGP region (Fig. 7). The annually averaged satellite based $\mathrm{NO}_{2} \mathrm{VCD}$ for 2014 was found to be $2.5 \times 10^{15}$ molecules $\mathrm{cm}^{-2}$ around the observation site, with the highest $\mathrm{NO}_{2} \operatorname{VCD}\left(3.4 \times 10^{15}\right.$ molecules $\left.\mathrm{cm}^{-2}\right)$ found in the month of December. The lowest $\mathrm{NO}_{2} \mathrm{VCD}$ $\left(1.9 \times 10^{15}\right.$ molecules $\left.\mathrm{cm}^{-2}\right)$ was observed in the month of February. During the months of July, August and September 2014 , higher $\mathrm{NO}_{2}$ VCDs $\left(\sim 8 \times 10^{15}\right.$ molecules $\left.\mathrm{cm}^{-2}\right)$ were observed over the two thermal power plants situated to the south of the measurement site than over the measurement site $\left(\sim 2.2 \times 10^{15}\right.$ molecules $\left.\mathrm{cm}^{-2}\right)$. To investigate the effect of long-range transport from the thermal power plants on the observed $\mathrm{NO}_{2}$ at the measurement site, we computed the 12-hour and 24-hour back trajectories reaching the site every hour using the HYbrid Single-Particle Lagrangian Integrated Trajectory (HYSPLIT) model (Draxler and Hess, 1998). The area around the measurement site was divided into five sectors; with geometric north being $0^{\circ}$, the sectors were: Sector 1: $305-35^{\circ}$; Sector 2: 35-75'; Sector 3: $75-125^{\circ}$; Sector 4: $125-185^{\circ}$ and Sector 5: $185-$ $305^{\circ}$ (Fig. 1). Sectors 1 and 2 represent the nearby town of Mirzapur (which is closest to the measurement site, at a distance of $10 \mathrm{~km}$ ) and the city of Varanasi (at a distance of $60 \mathrm{~km}$ ) (Fig. 1). Sector 3 represents a vegetated area to the east of the measurement site. Sector 4 represents the region with the two thermal power plants, and Sector 5 represents the rural IGP region. For each of the 12-/24-h back trajectories, information about where (sector-wise) the air parcel spends at least $70 \%$ of its total time before arriving at the measurement site was extracted. The boxand-whisker plot in Fig. 8 (left column) shows the sectorwise contribution to the observed $\mathrm{NO}_{2}$, where the air parcel spends at least $70 \%$ of its time in a particular sector (the top and bottom panels correspond the 12-h and 24-h back trajectories, respectively). The median for the corresponding sector along with the $75^{\text {th }}$ and $25^{\text {th }}$ percentile values are indicated in the box. The whiskers correspond to the 2.7 sigma $(99.3 \%)$ when the data are normally distributed. The median $\mathrm{NO}_{2}$ value for air parcels passing over Sector 4 was the highest ( 1 ppbv and 1.44 ppbv for 

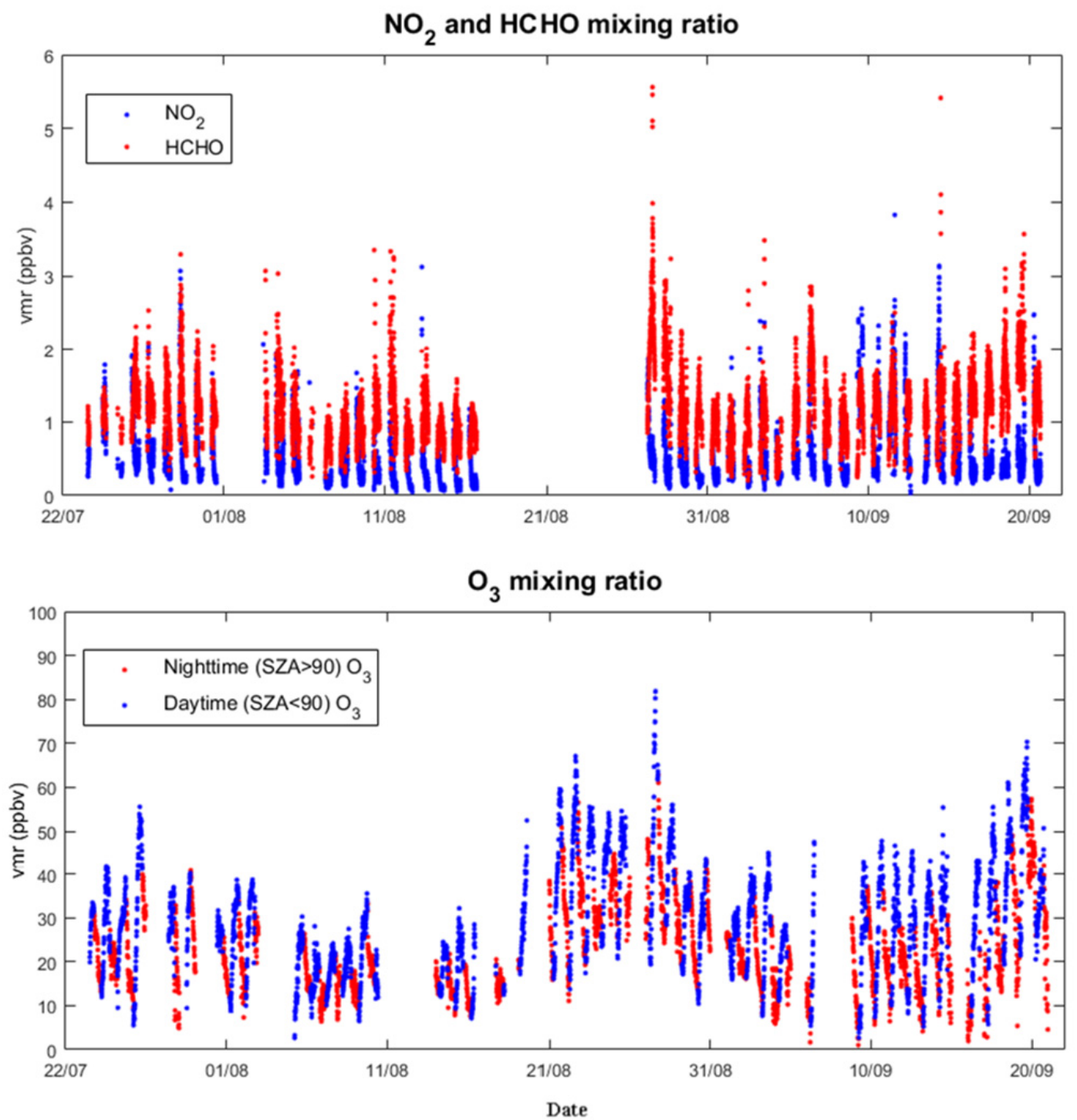

Fig. 5. Time series for $\mathrm{NO}_{2}, \mathrm{HCHO}$ and $\mathrm{O}_{3}$ vmr. The top panel shows $\mathrm{NO}_{2}$ (blue dots) and $\mathrm{HCHO}$ (red dots) mixing ratios. The bottom panel shows daytime (blue dots) and nighttime (red dots) $\mathrm{O}_{3}$ mixing ratios.
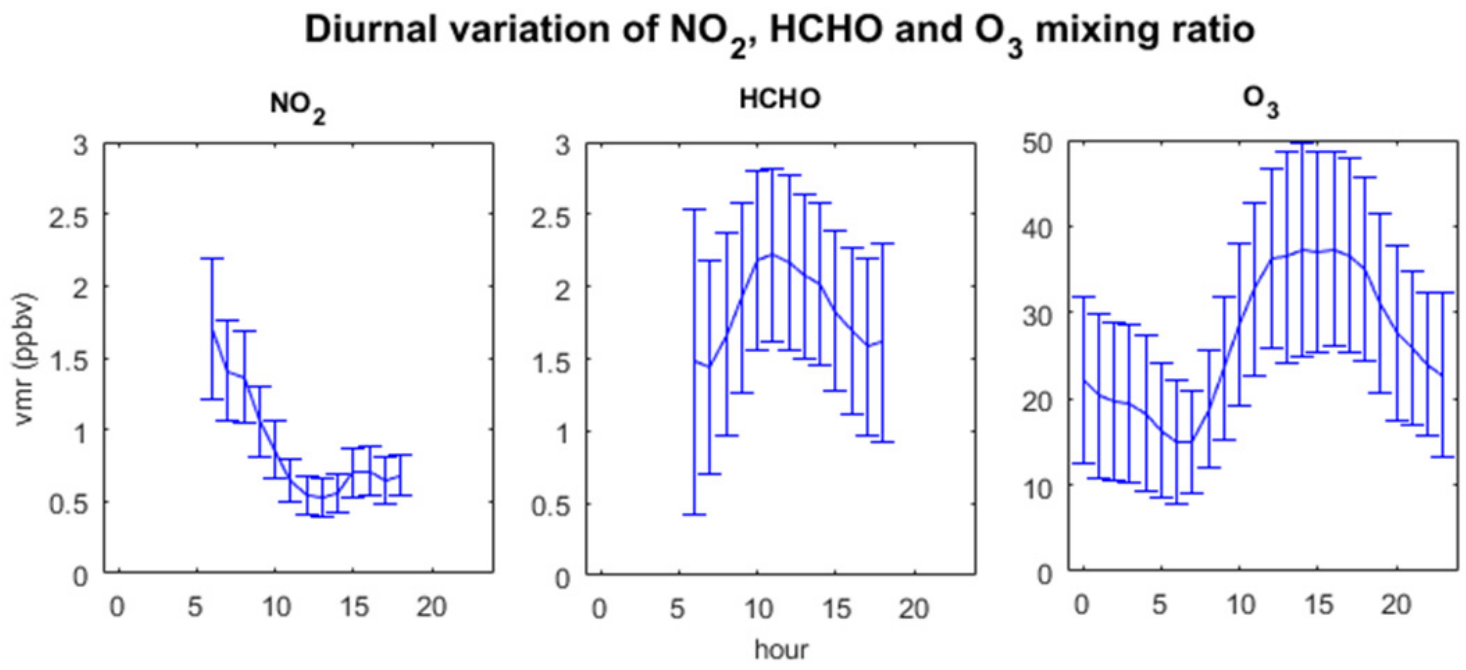

Fig. 6. Diurnal variation in $\mathrm{NO}_{2}, \mathrm{HCHO}$ and $\mathrm{O}_{3}$ mixing ratios during CAIPEEX-2014. The error bars represent the standard deviations. 

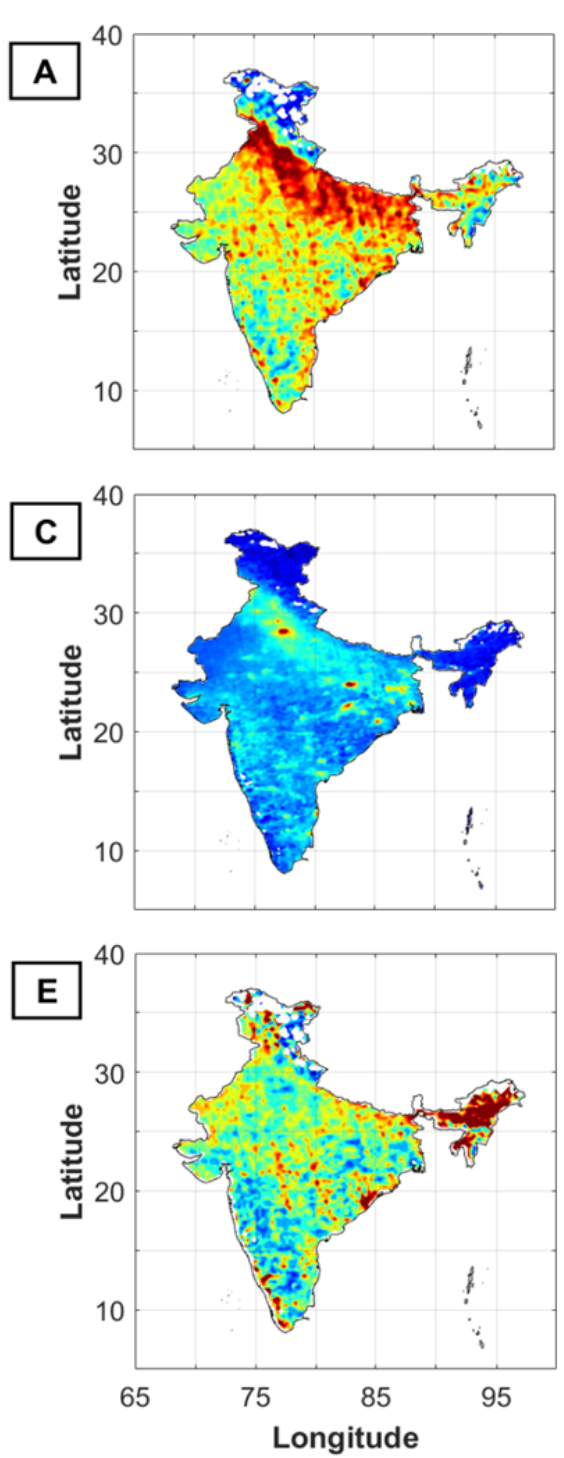

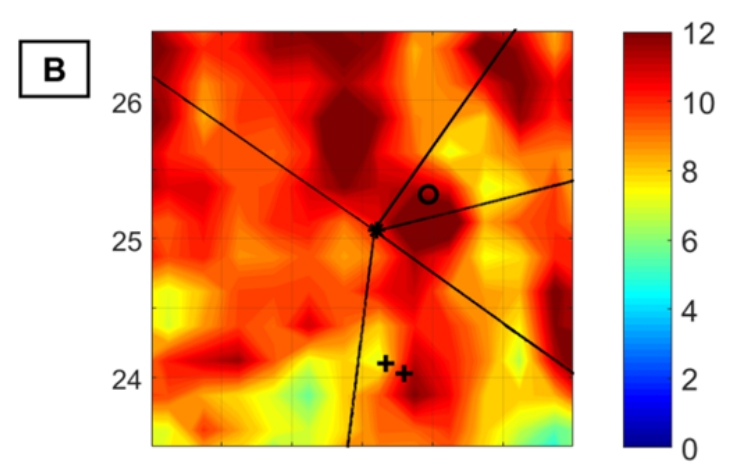

D
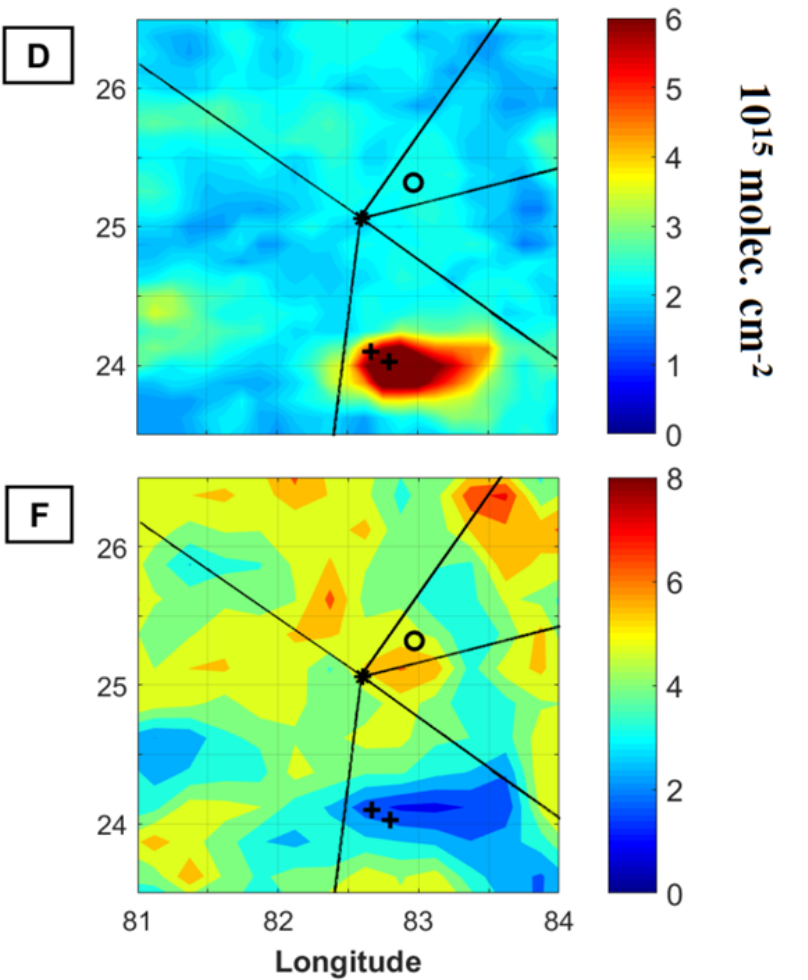

Fig. 7. Satellite-based (OMI) vertical columns of $\mathrm{NO}_{2}$ and $\mathrm{HCHO}$ for the months of July, August and September 2014. (A) $\mathrm{HCHO}$ over India. (B) HCHO over the CAIPEEX-2014 site. (C) $\mathrm{NO}_{2}$ over India. (D) $\mathrm{NO}_{2}$ contour over the CAIPEEX-2014 site. (E) $\mathrm{HCHO} / \mathrm{NO}_{2}$ ratio over India. (F) $\mathrm{HCHO} / \mathrm{NO}_{2}$ ratio over the CAIPEEX-2014 site. "o" represents the city of Varanasi, and "+" indicates the thermal power plants.

12-h and 24-h back trajectories), which indicates the transport of $\mathrm{NO}_{2}$ from the power plants to the CAIPEEX2014 site. Sector 5 and Sector 3 show the lowest median values ( $0.51 \mathrm{ppbv}$ and $0.51 \mathrm{ppbv})$ for the 12 -h and $24-\mathrm{h}$ back trajectories, respectively. This is expected, considering that there are no large sources of $\mathrm{NO}_{\mathrm{x}}$ in these two sectors.

All the sectors were found to have outliers beyond the upper 2.7 sigma limit. For the 24-h back trajectories, Sectors 1, 2, 3, 4 and 5 had 9.2\%, 0.8\%,6.8\%, 2.9\% and $5.6 \%$ outliers, respectively. For the 12 -h back trajectories, Sectors $1,2,3,4$ and 5 had $8.1 \%, 3.4 \%, 7.8 \%, 0.4 \%$ and $6 \%$ outliers, respectively. The probable sources of the outliers were (1) contamination of the air parcels with air parcels coming from Sector 4 (associated with high $\mathrm{NO}_{2}$ from the power plants) and (2) local sources originating from automobiles, as there was a road close to the measurement site. To test the first hypothesis, air parcels which travelled over the power plants, even though their residence time was larger in other sectors, were identified. The reasoning behind this was that if the power plants were the source of outliers, then these air parcels would contain more outliers.

To identify the effect of power plant emissions on $\mathrm{NO}_{2}$ outliers, we check whether the air parcels from the power plants have contaminated the air parcels which have travelled predominantly over other sectors. We identified the region over the power plants, which shows higher $\mathrm{NO}_{2}$ VCDs $\left(>6 \times 10^{15}\right.$ molecules $\left.\mathrm{cm}^{-2}\right)$ in the satellite observations. We found that a box within latitudes $23.5^{\circ}-24.5^{\circ}$ and longitudes $82.5^{\circ}-83.5^{\circ}$ contained the highest $\mathrm{NO}_{2}$ VCDs. We identified air parcels that have travelled through this box in the past 12 or 24 hours. Fig. 9 shows all the $\mathrm{NO}_{2}$ data (blue dots) along with the outlier $\mathrm{NO}_{2}$ data (red dots). Data points which correspond to air parcels passing 


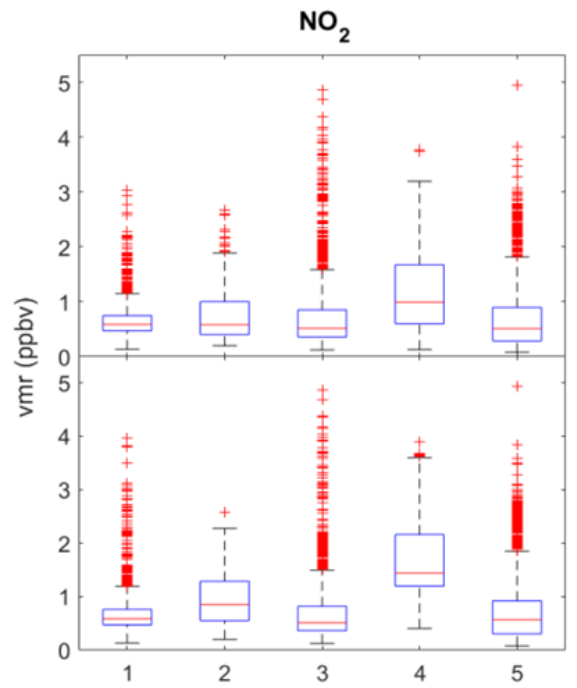

\section{Sectorwise plot for $\mathrm{NO}_{2}, \mathrm{HCHO}$ and $\mathrm{O}_{3}$}
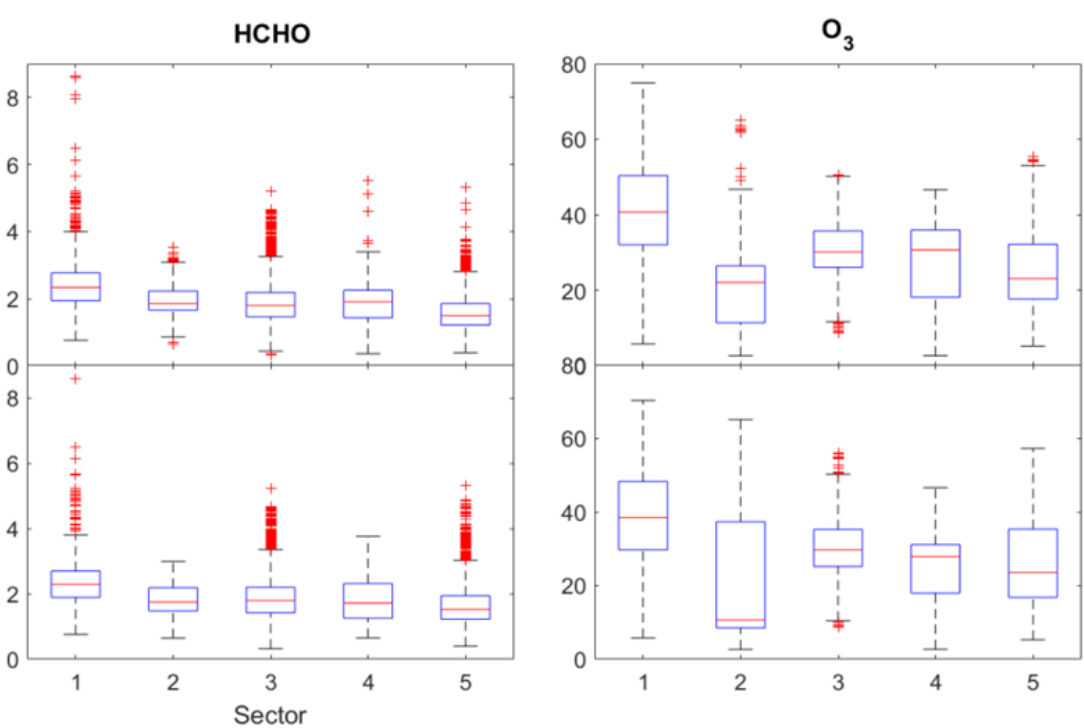

Fig. 8. Box-and-whisker plot of $\mathrm{NO}_{2}, \mathrm{HCHO}$ and $\mathrm{O}_{3}$ mixing ratios and the number of the sector where the air parcel has spent more than $70 \%$ of its time in the last $12 / 24$ hours. All the top panels correspond to the 12 -h back trajectory data, whereas the lower panels represent the 24-h back trajectory data.

$\mathrm{NO}_{2}$ mixing ratio and effect of power plant on outliers

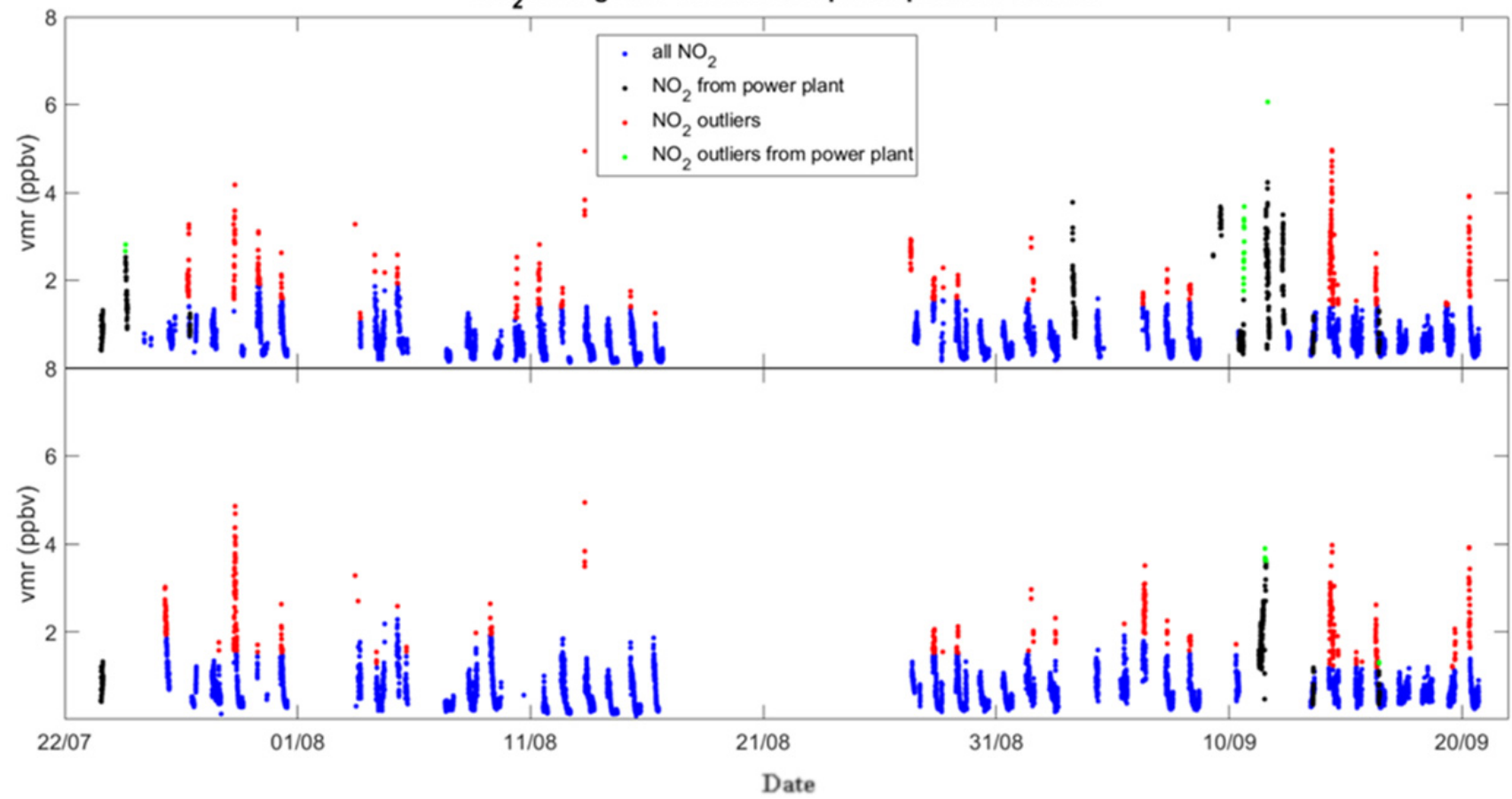

Fig. 9. Time series of $\mathrm{NO}_{2}$ and $\mathrm{NO}_{2}$ outliers from different sectors. The blue dots represent all $\mathrm{NO}_{2}$ data; the red dots represent $\mathrm{NO}_{2}$ outliers from different sectors; the black dots represent $\mathrm{NO}_{2}$ from parcels corresponding to the power plant region; the green dots represent $\mathrm{NO}_{2}$ outliers affected by emissions from the power plant region. The top and bottom panels represent $12-\mathrm{h}$ and $24-\mathrm{h}$ back trajectory plots.

through the box are represented with black dots. Outliers that correspond to air parcels passing through the box are represented with green dots. The top and bottom panels represent $12-\mathrm{h}$ and $24-\mathrm{h}$ back trajectory plots. Out of 48 days of observation, 35 days contained data points which were identified as outliers in the 12-h back trajectories (480 total outlier data points out of 7412 data points). For 24-h back trajectories, 31 days contained outlier data points in the different sectors (465 total outlier data points out of 7106 data points). For 12-h back trajectories, on 
8 days, air parcels passed through the box containing high $\mathrm{NO}_{2}$ VCDs (492 data points), and out of these 8 days, only 3 days (43 data points) contained outlier data points. For 24-h back trajectories, 6 days contained air parcels that passed through the box containing high $\mathrm{NO}_{2}$ VCDs $(255$ data points), of which 2 days (15 data points) had outlier data points. This leads us to conclude that contamination of air parcels coming from power plants do not explain the outlier $\mathrm{NO}_{2}$ data points. Hence, we conclude that the outliers are not caused by long-range transport but rather by local emissions.

The reason behind the fact that Sector 4 contains the fewest outliers is that the median and sigma values $(2.7$ sigma values limiting the whiskers) are higher in Sector 4 compared to other sections due to higher emissions from the power plants. Most elevated $\mathrm{NO}_{2}$ values caused by the local effect are within the 2.7 sigma range. It should be noted that for Sector 2, the lack of outliers could also be a result of sampling bias, as during the ASM season, the dominant wind pattern is south-westerly. However, for other sectors, the median and sigma values (2.7 sigma values limiting the whiskers) are lower, and most elevated $\mathrm{NO}_{2}$ values caused by local emissions are observed as outliers. It is thus highly probable that the main cause behind the presence of large outliers is local emissions from automobiles on the highway to the south or the nearby marketplace mentioned earlier.

\section{HCHO}

Similar to $\mathrm{O}_{4}$ and $\mathrm{NO}_{2}$, the HCHO DSCDs were found to have lower values for higher elevation angles, except the three lowest elevation angles of $2^{\circ}, 1^{\circ}$ and $0.5^{\circ}$, due to the presence of aerosols in the boundary layer. This indicates that most of the HCHO is present near the surface with a decreasing gradient upwards, although the decrease was not as strong as that for $\mathrm{NO}_{2}$ (Fig. 4). The average RMS and detection limit for HCHO DSCDs were $4.1 \times 10^{-4}$ and $1.06 \times 10^{15}$ molecules $\mathrm{cm}^{-2}$, respectively, at the $1^{\circ}$ elevation angle. The average HCHO DSCD at the $1^{\circ}$ elevation angle was $3.56 \times 10^{16}$ molecules $\mathrm{cm}^{-2}$ with a maximum DSCD of $8.06 \times 10^{16}$ molecules $\mathrm{cm}^{-2}$ (Fig. 4).

The average HCHO mixing ratio was found to be $1.93 \pm$ $0.60 \mathrm{ppbv}$, with values ranging between $0.32 \mathrm{ppbv}$ and $8.81 \mathrm{ppbv}$ (Fig. 5). The diurnal variation of $\mathrm{HCHO}$ is unlike $\mathrm{NO}_{2}$; $\mathrm{HCHO}$ was found to increase through the morning till 11:00 and then gradually decrease towards late evening (Fig. 6). This can be attributed to daytime photochemical oxidation of VOCs to form HCHO (R6)(R9). Photochemical oxidation is also the major sink process for HCHO (R10)-(R11), which is why after an increase in the morning hours, HCHO starts to reduce as destruction starts to dominate production.

The annually averaged satellite-based HCHO VCD for 2014 was $11.2 \times 10^{15}$ molecules $\mathrm{cm}^{-2}$ around the observation site, with the highest HCHO VCD $(15.6 \times$ $10^{15}$ molecules $\mathrm{cm}^{-2}$ ) found in the month of November. The lowest HCHO VCD $\left(6.6 \times 10^{15}\right.$ molecules $\left.\mathrm{cm}^{-2}\right)$ was observed in the month of September. Satellite retrieved HCHO VCDs averaged for the months of July, August and
September of 2014 were found to be within 8-12 $\times$ $10^{15}$ molecules $\mathrm{cm}^{-2}$ around the observation site (Fig. 7) without any larger spatial differences, making it more homogeneous compared to $\mathrm{NO}_{2}$. The box-and-whisker plot for $\mathrm{HCHO}$ (Fig. 8, middle column) with 12-h back trajectories shows that Sector 1 had the highest median value $(2.34 \mathrm{ppbv})$ and Sector 5 displayed the lowest median value (1.5 ppbv). For the $24-\mathrm{h}$ back trajectory plot, Sector 1 has the highest (2.29 ppbv) and Sector 5 has the lowest $(1.53 \mathrm{ppbv})$ median value. Compared to $\mathrm{NO}_{2}$, the $\mathrm{HCHO}$ does not show significant differences between different sectors. This can also be seen in the satellite observations (Fig. 7). Unlike $\mathrm{NO}_{2}$, which has a significant source in Sector 4, there is no similarly strong "point" source for $\mathrm{HCHO}$ in any sector. The numbers of outliers are also lower for $\mathrm{HCHO}$ compared to $\mathrm{NO}_{2}$. For 24-h back trajectories, Sectors 1, 2, 3, 4 and 5 had 2.74\%, 0.0\%, $3.92 \%, 0.0 \%$ and $5.47 \%$ outliers, respectively. For $12-\mathrm{h}$ back trajectories, Sectors 1, 2, 3, 4 and 5 had $3.58 \%$, $2.78 \%, 4.63 \%, 1.03 \%$ and $3.32 \%$ outliers, respectively. The source for $\mathrm{HCHO}$ outliers also seems to be local anthropogenic emissions, which include biomass burning and emissions from automobiles.

\section{Ozone}

For this study, we analysed $\mathrm{O}_{3}$ data for the period of 23 July 2014 to 20 September 2014, which coincides with the MAX-DOAS observations. Being located near a highway, $\mathrm{O}_{3}$ mixing ratios were observed to be affected by emissions from vehicles. To discard effects from nearby emissions, ozone data was filtered for spikes from periods when vehicles passed close to the site. The filtered data was averaged every 10 minutes to match the MAX-DOAS observations. Fig. 6 shows the time-series for $\mathrm{O}_{3}$ during the CAIPEEX-2014 campaign.

The blue points in the plot represent the ozone for SZA $<90^{\circ}$, i.e., daytime ozone. The red points represent data for $\mathrm{SZA}>90^{\circ}$, i.e., nighttime ozone. The average $\mathrm{O}_{3}$ mixing ratio during daytime (solar zenith angle $<90^{\circ}$ ) was $30 \pm$ 13 ppbv (range: $2.7-81.9 \mathrm{ppbv}$ ), and during the nighttime (solar zenith angle $>90^{\circ}$ ), the mean was $22.5 \pm 10.2 \mathrm{ppbv}$ (range: $1-63$ ppbv). The right hand panel in Fig. 6 shows the hourly diurnal variation of $\mathrm{O}_{3}$ with the corresponding standard deviation. Observed $\mathrm{O}_{3}$ levels were at the lowest during the early morning (06:00-07:00) and increased during the daytime due to photochemical production. The $\mathrm{O}_{3}$ mixing ratios reached a peak around 12:00 and remained elevated until 16:00. In the presence of solar radiation, $\mathrm{NO}_{2}$ photochemically dissociates to $\mathrm{NO}$ and $\mathrm{O}\left({ }^{3} \mathrm{P}\right)$ and results in the formation of $\mathrm{O}_{3}$ per reactions described in the introduction. During midday, ozone concentrations reach an equilibrium, which continues until the late afternoon. During the evening, there is a gradual decrease due to the lack of photochemical production, which continues after sunset. At night, $\mathrm{O}_{3}$ oxidises olefins, $\mathrm{NO}, \mathrm{NO}_{2}$ etc.; this contributes to a decrease in the $\mathrm{O}_{3}$ concentrations. The diurnal trend for ozone (Fig. 6) matches with the previously observed pattern at sub-urban sites in India (Jain et al., 2005; Beig et al., 2007; Reddy et al., 2011; Ojha et al., 2012). 
Fig. 8 represents a box-and-whisker plot for daytime $\left(\mathrm{SZA}<90^{\circ}\right) \mathrm{O}_{3}$ from corresponding sectors as discussed above (top right plot is for $12-\mathrm{h}$ back trajectories, and bottom right plot is for 24-h back trajectories). For both 12-h and 24-h back trajectories, Sectors 1 and 2 have the highest and lowest median values (Sector 1 with $40.7 \mathrm{ppbv}$ and $38.5 \mathrm{ppbv}$ for $12 \mathrm{-h}$ and $24-\mathrm{h}$ back trajectories, respectively; Sector 2 with $22.1 \mathrm{ppbv}$ and $10.7 \mathrm{ppbv}$ for 12-h and 24-h back trajectories, respectively).

It is well known that at low $\mathrm{NO}_{\mathrm{x}}$ concentrations, $\mathrm{O}_{3}$ formation is linearly proportional to $\mathrm{NO}_{\mathrm{x}}$ concentrations and is independent of VOC concentration (Chameides et al., 1992), whereas in regions with lower VOC concentrations, ozone production is inversely proportional to $\mathrm{NO}_{\mathrm{x}}$ but linearly proportional to VOCs. Chameides et al. (1992) reported that $\mathrm{HCHO} / \mathrm{NO}_{2}$ ratio can be indicative of surface ozone sensitivity towards $\mathrm{NO}_{\mathrm{x}}$ limited and VOC limited regimes. Using satellite based observation, Martin et al. (2004) reported that $\mathrm{HCHO} / \mathrm{NO}_{2}$ ratio $<1$ is an indication of VOC limited regime and $>1$ is an indication of $\mathrm{NO}_{\mathrm{x}}$ limited regime for ozone formation. In a recent study, Schroeder et al. (2017) further studied the critical ratio for $\mathrm{VOC}$ and $\mathrm{NO}_{\mathrm{x}}$ limited regimes. They found that $\mathrm{HCHO} / \mathrm{NO}_{2}$ column ratio from 1.1 to 4.3 cannot be reliably classified as either $\mathrm{NO}_{\mathrm{x}}$ or VOC limited regime, depending upon regional variability. From satellite data, the $\mathrm{HCHO} / \mathrm{NO}_{2}$ column ratio was found to be $>4$ over the CAIPEEX-2014 site (bottom left and bottom right panels in Fig. 4). The average $\mathrm{HCHO} / \mathrm{NO}_{2}$ from the ground based instruments was found to be $>2$. Both the results indicate that the CAIPEEX-2014 site is most likely an $\mathrm{NO}_{\mathrm{x}}$ limited region; hence, the ozone formation should be dependent on the $\mathrm{NO}_{\mathrm{x}}$ concentrations (Martin et al., 2004), although the ratio is within the "uncertain range". We studied the correlation between hourly averaged $\mathrm{HCHO}$ and ozone mixing ratios, and a positive correlation $(\mathrm{R}=0.65, p<0.001)$ was observed over the observation period. The hourly averaged $\mathrm{NO}_{2}$ and ozone mixing ratio displayed a slight negative correlation $(\mathrm{R}=-0.2, p=0.005)$. The daily averaged HCHO and ozone mixing ratios also yielded a positive correlation $(\mathrm{R}=$ $0.78, p<0.001)$, while the correlation between daily averaged $\mathrm{NO}_{2}$ and ozone mixing ratios was insignificant. Hourly averaged $\mathrm{HCHO}$ and $\mathrm{NO}_{2}$ mixing ratio did not show any significant correlation, suggesting different sources. The correlational analysis suggests that the ozone mixing ratios are more dependent on the $\mathrm{HCHO}$ mixing ratios, contrary to what is expected from the observed $\mathrm{HCHO} / \mathrm{NO}_{2}$ ratio. However, on close inspection of variations within short periods, it is found that ozone resembles neither the variation of $\mathrm{HCHO}$ nor $\mathrm{NO}_{2}$. As mentioned above, the $\mathrm{O}_{3}$ back trajectories indicate higher daytime $\mathrm{O}_{3}$ mixing ratios associated with air masses coming from Sector 1, whereas $\mathrm{NO}_{2}$ is higher in air masses from Sector 4. This suggests that $\mathrm{O}_{3}$ formation at the CAIPEEX-2014 site was more affected by local production than long-range transport from the power plants, during which elevated $\mathrm{NO}_{2}$ was observed. The city of Mirzapur (Sector 1), being closer to the measurement site compared to the city of Varanasi, shows an effect on the observed $\mathrm{O}_{3}$ concentrations, as can be seen from the sectorial analysis.

\section{CONCLUSIONS}

In this study, we reported the $\mathrm{NO}_{2}$ and $\mathrm{HCHO}$ concentrations, obtained via MAX-DOAS technique, as well as the surface $\mathrm{O}_{3}$ concentrations measured during the ASM season as part of the Cloud Aerosol Interaction and Precipitation Enhancement Experiment (CAIPEEX-2014). We discussed the effect of long-range transport on the $\mathrm{NO}_{2}$ and $\mathrm{HCHO}$ mixing ratios and on $\mathrm{O}_{3}$ production during the campaign. The $\mathrm{NO}_{2}$ mixing ratios ranged from $0.08 \mathrm{ppbv}$ to $6.06 \mathrm{ppbv}$ with an average of $0.81 \pm 0.20 \mathrm{ppbv}$. Observations indicated that most of the $\mathrm{NO}_{2}$ lay near the surface with a decreasing gradient upward. The $\mathrm{NO}_{2}$ mixing ratios decreased from early in the morning till midday and then increased during the afternoon. Through satellite observation, an $\mathrm{NO}_{2}$ emission hotspot was identified $\sim 110 \mathrm{~km}$ to the south of the CAIPEEX-2014 site, where two large thermal power plants are located, and air parcels travelling from the direction of these power plants exhibited higher $\mathrm{NO}_{2}$ mixing ratios. Local emissions (from automobiles on a highway near the campaign site and from a nearby marketplace) also contributed to the high $\mathrm{NO}_{2}$ mixing ratios. The $\mathrm{HCHO}$ mixing ratios ranged from $0.32 \mathrm{ppbv}$ to $8.81 \mathrm{ppbv}$ with an average of $1.93 \pm 0.60 \mathrm{ppbv}$. Due to the daytime photochemical oxidation of VOCs, which resulted in the formation of $\mathrm{HCHO}$, the $\mathrm{HCHO}$ increased during the morning until 11:00. Satellite observations indicated that the concentrations of $\mathrm{HCHO}$ around the campaign site were almost homogeneous compared to those of $\mathrm{NO}_{2}$. The average $\mathrm{O}_{3}$ mixing ratio observed during the daytime and the nighttime was $30 \pm 13 \mathrm{ppbv}$ (range: $2.7-81.9 \mathrm{ppbv}$ ) and $22.5 \pm 10.2 \mathrm{ppbv}$ (range: $1-63 \mathrm{ppbv}$ ), respectively. The $\mathrm{O}_{3}$ mixing ratios were low in the early morning (06:00-07:00) but increased during the daytime due to photochemical production, reaching their maximum values around 12:00. Following this peak, they remained steady until 16:00, after which they decreased through the evening. Furthermore, our results suggested that the background surface $\mathrm{O}_{3}$ mixing ratio depended on the $\mathrm{HCHO}$ mixing ratio. Based on the sectorial analysis, surface $\mathrm{O}_{3}$ concentrations at the CAIPEEX-2014 site were contributed by local emissions rather than long-range-transported precursors.

\section{ACKNOWLEDGEMENTS}

The Indian Institute of Tropical Meteorology is funded by the Ministry of Earth Sciences, Government of India. We thank all the participants of the CAIPEEX-2014 campaign for support during the measurement period.

\section{REFERENCES}

Abbot, D.S., Palmer, P.I., Martin, R.V., Chance, K.V., Jacob, D.J. and Guenther, A. (2003). Seasonal and interannual variability of North American isoprene emissions as determined by formaldehyde column measurements from space. Geophys. Res. Lett. 30: 
1999-2002.

Andreae, M.O. and Crutzen, P.J. (1997). Atmospheric aerosols: Biogeochemical sources and role in atmospheric chemistry. Science 276: 1052-1058.

Andreae, M.O. and Merlet, P. (2001). Emission of trace gases and aerosols from biomass burning. Global Biogeochem. Cycles 15: 955-966.

Atkinson, R. (2000). Atmospheric chemistry of VOCs and $\mathrm{NO}_{x}$. Atmos. Environ. 34: 2063-2101.

Barkley, M.P., Smedt, I.D., Van Roozendael, M., Kurosu, T.P., Chance, K., Arneth, A., Hagberg, D., Guenther, A., Paulot, F., Marais, E. and Mao, J. (2013). Top-down isoprene emissions over tropical South America inferred from SCIAMACHY and OMI formaldehyde columns. $J$. Geophys. Res. 118: 6849-6868.

Barrie, L.A., Bottenheim, J.W., Schnell, R.C., Crutzen, P.J. and Rasmussen, R.A. (1988). Ozone destruction and photochemical reactions at polar sunrise in the lower Arctic atmosphere. Nature 334: 138-141.

Beig, G., Gunthe, S. and Jadhav, D.B. (2007). Simultaneous measurements of ozone and its precursors on a diurnal scale at a semi urban site in India. J. Atmos. Chem. 57: 239-253.

Burnett, R.T., Stieb, D., Brook, J.R., Cakmak, S., Dales, R., Raizenne, M., Vincent, R. and Dann, T. (2004). Associations between short-term changes in nitrogen dioxide and mortality in Canadian cities. Arch. Environ. Health 59: 228-236.

Carlier, P., Hannachi, H. and Mouvier, G. (1986). The chemistry of carbonyl compounds in the atmosphere-A review. Atmos. Environ. 20: 2079-2099.

Chameides, W.L., Fehsenfeld, F., Rodgers, M.O., Cardelino, C., Martinez, J., Parrish, D., Lonneman, W., Lawson, D.R., Rasmussen, R.A., Zimmerman, P., Greenberg, J., Mlddleton, P. and Wang, T. (1992). Ozone precursor relationships in the ambient atmosphere. J. Geophys. Res. 97: 6037.

Chan, A.W.H., Chan, M.N., Surratt, J.D., Chhabra, P.S., Loza, C.L., Crounse, J.D., Yee, L.D., Flagan, R.C., Wennberg, P.O. and Seinfeld, J.H. (2010). Role of aldehyde chemistry and $\mathrm{NO}_{\mathrm{x}}$ concentrations in secondary organic aerosol formation, Atmos. Chem. Phys. 10: 7169-7188.

Chance, K., Palmer, P.I., Spurr, R.J.D., Martin, R.V., Kurosu, T.P. and Jacob, D.J. (2000). Satellite observations of formaldehyde over North America from GOME. Geophys. Res. Lett. 27: 3461-3464.

Chance, K. and Kurucz, R. (2010). An improved highresolution solar reference spectrum for earth's atmosphere measurements in the ultraviolet, visible, and near infrared. J. Quant. Spectrosc. Radiat. Transfer 111: 1289-1295.

Constantin, D.E., Merlaud, A., Roozendael, M.V., Voiculescu, M., Fayt, C., Hendrick, F., Pinardi, G. and Georgescu, L. (2013). Measurements of tropospheric $\mathrm{NO}_{2}$ in Romania using a zenith-sky mobile DOAS system and comparisons with satellite observations. Sensors 13: 3922-3940.

Crutzen, P.J. (1970). The influence of nitrogen oxides on the atmospheric ozone content. Q. J. R. Meteorolog. Soc. 96: 320-325.

Crutzen, P.J. (1974). Photochemical reactions initiated by and influencing ozone in unpolluted tropospheric air. Tellus 26: 47-57.

Crutzen, P.J. (1979). The role of $\mathrm{NO}$ and $\mathrm{NO}_{2}$ in the chemistry of the troposphere and stratosphere. Annu. Rev. Earth Planet. Sci. 7: 443-472.

Danckaert, T. (2014). QDOAS Software user manual. IASB/BIRA, Uccle, Belgium.

Debaje, S. and Kakade, A. (2006). Weekend ozone effect over rural and urban site in India. Aerosol Air Qual. Res. 6: 322-333.

Desqueyroux, H., Pujet, J.C., Prosper, M., Squinazi, F. and Momas, I. (2002). Short-term effects of low-level air pollution on respiratory health of adults suffering from moderate to severe asthma. Environ. Res. 89: 29-37.

Draxler, R.R. and Hess, G.D. (1998). An Overview of the HYSPLIT 4 Modelling System for Trajectories, Dispersion, and Deposition. Aust. Meteorol. Mag. 47: 295-308

Dutta, C., Chatterjee, A., Jana, T., Mukherjee, A. and Sen, S. (2010). Contribution from the primary and secondary sources to the atmospheric formaldehyde in Kolkata, India. Sci. Total Environ. 408: 4744-4748.

Finlayson-Pitts, B.J. and Pitts, J.N. (2000). Chapter 2 - the atmospheric system. In Chemistry of the upper and lower atmosphere, Finlayson-Pitts, B.J. and Pitts, J.N. (Eds.), Academic Press, San Diego, pp. 15-42.

Fishman, J. and Crutzen, P.J. (1978). The origin of ozone in the troposphere. Nature 274: 855-858.

Frieß, U., Monks, P.S., Remedios, J.J., Rozanov, A., Sinreich, R., Wagner, T. and Platt, U. (2006). MAXDOAS $\mathrm{O}_{4}$ measurements: A new technique to derive information on atmospheric aerosols: 2. Modeling studies. J. Geophys. Res. 111: D14203.

Fu, T.M., Jacob, D.J., Palmer, P.I., Chance, K., Wang, Y.X., Barletta, B., Blake, D.R., Stanton, J.C. and Pilling, M.J. (2007). Space-based formaldehyde measurements as constraints on volatile organic compound emissions in east and south Asia and implications for ozone. $J$. Geophys. Res. 112: D06312.

Geiger, H., Kleffmann, J. and Wiesen, P. (2002). Smog chamber studies on the influence of diesel exhaust on photosmog formation. Atmos. Environ. 36: 1737-1747.

Ghude, S.D., Fadnavis, S., Beig, G., Polade, S.D. and van der A, R.J. (2008). Detection of surface emission hot spots, trends, and seasonal cycle from satellite-retrieved $\mathrm{NO}_{2}$ over India. J. Geophys. Res. 113: D20305.

Ghude, S.D., Kulkarni, S.H., Jena, C., Pfister, G.G., Beig, G., Fadnavis, S. and van der A.R.J. (2013). Application of satellite observations for identifying regions of dominant sources of nitrogen oxides over the Indian Subcontinent, J. Geophys. Res. 118: 1075-1089.

Ghude, S.D., Jena, C., Chate, D.M., Beig, G., Pfister, G.G., Kumar, R. and Ramanathan, V. (2014). Reductions in Indias crop yield due to ozone. Geophys. Res. Lett. 41: 5685-5691.

Gómez Martín, J.C., Mahajan, A.S., Hay, T.D., Prados- 
Román, C., Ordóñez, C., MacDonald, S.M., Plane, J.M.C., Sorribas, M., Gil, M., Mora, J.F.P., Reyes, M.V.A., Oram, D.E., Leedham, E. and Saiz-Lopez, A. (2013). Iodine chemistry in the eastern Pacific marine boundary layer. J. Geophys. Res. 118: 887-904.

Gonzi, S., Palmer, P.I., Barkley, M.P., Smedt, I.D. and Roozendael, M.V. (2011). Biomass burning emission estimates inferred from satellite column measurements of HCHO: Sensitivity to co-emitted aerosol and injection height. Geophys. Res. Lett. 38: L14807.

Grainger, J.F. and Ring, J. (1962). Anomalous fraunhofer line profiles. Nature 193: 762-762.

Hak, C., Pundt, I., Kern, C., Platt, U., Dommen, J., Ordóñez, C., Prévôt, A.S.H., Junkermann, W., Astorga-Lloréns, C., Larsen, B.R., Mellqvist, J., Strandberg, A., Yu, Y., Galle, B., Kleffmann, J., Lörzer, J.C., Braathen, G.O. and Volkamer, R. (2005). Intercomparison of four different in-situ techniques for ambient formaldehyde measurements in urban air. Atmos. Chem. Phys. 5: 2881-2900.

Hendrick, F., Müller, J., Clémer, K., Wang, P., Mazière, M.D., Fayt, C., Gielen, C., Hermans, C., Ma, J.Z., Pinardi, G., Stavrakou, T., Vlemmix, T. and Roozendael, M.V. (2014). Four years of ground-based MAX-DOAS observations of $\mathrm{HONO}$ and $\mathrm{NO}_{2}$ in the Beijing area. Atmos. Chem. Phys. 14: 765-781.

Herndon, S.C., Jayne, J.T., Zahniser, M.S., Worsnop, D.R., Knighton, B., Alwine, E., Lamb, B.K., Zavala, M., Nelson, D.D., McManus, J.B., Shorter, J.H., Canagaratna, M.R., Onasch, T.B. and Kolb, C.E. (2005). Characterization of urban pollutant emission fluxes and ambient concentration distributions using a mobile laboratory with rapid response instrumentation. Faraday Discuss. 130: 327-339.

Hilboll, A., Richter, A. and Burrows, J.P. (2013). Long-term changes of tropospheric $\mathrm{NO}_{2}$ over megacities derived from multiple satellite instruments. Atmos. Chem. Phys. 13: 4145-4169.

Holton, J.R., Haynes, P.H., Mcintyre, M.E., Douglass, A.R. and Rood, B., (1995). Stratosphere-troposphere exchange. Rev. Geophys. 33: 403-439.

Hönninger, G., Friedeburg, C.V. and Platt, U. (2004). Multi axis differential optical absorption spectroscopy (MAX-DOAS). Atmos. Chem. Phys. 4: 231-254.

Hoque, H.M.S., Irie, H., Damiani, A., Rawat, P. and Naja, M. (2018). First simultaneous observations of formaldehyde and glyoxal by MAX-DOAS in the Indo-Gangetic Plain region. Sola 14: 159-164.

Huijnen, V., Williams, J., Weele, M.V., Noije, T.V., Krol, M., Dentener, F., Segers, A., Houweling, S., Peters, W., Laat, J. D., Boersma, F., Bergamaschi, P., Velthoven, P. V., Sager, P. L., Eskes, H., Alkemade, F., Scheele, R., Nédélec, P. and Pätz, H. (2010). The global chemistry transport model TM5: Description and evaluation of the tropospheric chemistry version 3.0. Geosci. Model Dev. 3: 445-473.

IPCC (2007). Climate change 2007: The physical science basis. Contribution of Working Group I to the Fourth Assessment Report of the Intergovernmental Panel on
Climate Change, Solomon, S., Qin, D., Manning, M., Chen, Z., Marquis, M., Averyt, K.B., Tignor, M. and Miller, H.L. (Eds.), Cambridge University Press, Cambridge, United Kingdom and New York, NY, USA.

Jacob, D.J. (2000). Heterogeneous chemistry and tropospheric ozone. Atmos. Environ. 34: 2131-2159.

Jaeglé, L., Steinberger, L., Martin, R.V. and Chance, K. (2005). Global partitioning of $\mathrm{NO}_{\mathrm{x}}$ sources using satellite observations: Relative roles of fossil fuel combustion, biomass burning and soil emissions. Faraday Discuss. 130: 407-423.

Jain, S.L., Arya, B.C., Kumar, A., Ghude, S.D. and Kulkarni, P.S. (2005). Observational study of surface ozone at New Delhi, India. Int. J. Remote Sens. 26: 3515-3524.

Johansson, M., Rivera, C., Foy, B. D., Lei, W., Song, J., Zhang, Y., Galle, B. and Molina, L. (2009). Mobile mini-DOAS measurement of the outflow of $\mathrm{NO}_{2}$ and HCHO from Mexico City. Atmos. Chem. Phys. 9: 56475653.

Khare, P., Satsangi, G. S., Kumar, N., Kumari, K.M. and Srivastava, S.S. (1997). Surface measurements of formaldehyde and formic and acetic acids at a subtropical semiarid site in India. J. Geophys. Res. 102: 18997-19005.

Khare, P., Satsangi, G., Kumar, N., Kumari, K.M. and Srivastava, S. (1997). $\mathrm{HCHO}, \mathrm{HCOOH}$ and $\mathrm{CH} 3 \mathrm{COOH}$ in air and rain water at a rural tropical site in North Central India. Atmos. Environ. 31: 3867-3875.

Lal, S., Naja, M. and Subbaraya, B. (2000). Seasonal variations in surface ozone and its precursors over an urban site in India. Atmos. Environ. 34: 2713-2724.

Lee, D., Köhler, I., Grobler, E., Rohrer, F., Sausen, R., Gallardo-Klenner, L., Olivier, J.G.J., Dentener, F.J. and Bouwman, A. (1997). Estimations of global no, emissions and their uncertainties. Atmos. Environ. 31: 1735-1749.

Logan, J.A., Prather, M.J., Wofsy, S.C. and Mcelroy, M.B. (1981). Tropospheric chemistry: A global perspective. $J$. Geophys. Res. 86: 7210-7254.

Mahajan, A.S., Martín, J.C., Hay, T.D., Royer, S., YvonLewis, S., Liu, Y., Hu, L., Prados-Roman, C., Ordóñez, C., Plane, J.M.C. and Saiz-Lopez, A. (2012). Latitudinal distribution of reactive iodine in the Eastern Pacific and its link to open ocean sources. Atmos. Chem. Phys. 12: 11609-11617.

Mahajan, A.S., Smedt, I.D., Biswas, M.S., Ghude, S., Fadnavis, S., Roy, C. and Roozendael, M.V. (2015). Inter-annual variations in satellite observations of nitrogen dioxide and formaldehyde over India. Atmos. Environ. 116: 194-201.

Mandal, P., Prakash, M. and Bassin, J.K. (2011). Impact of Diwali celebrations on urban air and noise quality in Delhi City, India. Environ. Monit. Assess. 184: 209-215.

Martin, R.V., Fiore, A.M. and Donkelaar, A.V. (2004). Space-based diagnosis of surface ozone sensitivity to anthropogenic emissions. Geophys. Res. Lett. 31: L06120.

Martin, R.V., Sioris, C.E., Chance, K., Ryerson, T.B., Bertram, T.H., Wooldridge, P.J., Cohen, R.C., Neuman, J.A., Swanson, A. and Flocke, F.M. (2006). Evaluation 
of space-based constraints on global nitrogen oxide emissions with regional aircraft measurements over and downwind of eastern North America. J. Geophys. Res. 111: D15308.

Mayer, H. (1999). Air pollution in cities. Atmos. Environ. 33: 4029-4037.

Mittal, M.L., Hess, P.G., Jain, S., Arya, B. and Sharma, C. (2007). Surface ozone in the Indian region. Atmos. Environ. 41: 6572-6584.

Molina, M.J. and Molina, L.T. (2004). Megacities and atmospheric pollution. J. Air Waste Manage. Assoc. 54: 644-680.

Morgan, P.B., Mies, T.A., Bollero, G.A., Nelson, R.L. and Long, S.P. (2006). Season-long elevation of ozone concentration to projected 2050 levels under fully openair conditions substantially decreases the growth and production of soybean. New Phytol. 170: 333-343.

Nair, P., Chand, D., Lal, S., Modh, K., Naja, M., Parameswaran, K., Ravindran, S. and Venkataramani, S. (2002). Temporal variations in surface ozone at Thumba $\left(8.6^{\circ} \mathrm{N}, 77^{\circ} \mathrm{E}\right)-\mathrm{A}$ tropical coastal site in India. Atmos. Environ. 36: 603-610.

Nair, P.R., Ajayakumar, R.S., David, L.M., Girach, I.A. and Mottungan, K. (2018). Decadal changes in surface ozone at the tropical station Thiruvananthapuram $\left(8.542^{\circ} \mathrm{N}, 76.858^{\circ} \mathrm{E}\right)$, India: Effects of anthropogenic activities and meteorological variability. Environ. Sci. Pollut. Res. 25: 14827-14843.

Nair, V.S., Moorthy, K.K., Alappattu, D.P., Kunhikrishnan, P.K., George, S., Nair, P.R., Babu, S.S., Abish, B., Satheesh, S.K., Tripathi, S.N., Niranjan, K., Madhavan, B.L., Srikant, V., Dutt, C.B.S., Badarinath, K.V.S. and Reddy, R.R. (2007). Wintertime aerosol characteristics over the Indo-Gangetic Plain (IGP): Impacts of local boundary layer processes and long-range transport. $J$. Geophys. Res. 112: D13205.

Naja, M. (2002). Surface ozone and precursor gases at Gadanki $\left(13.5^{\circ} \mathrm{N}, 79.2^{\circ} \mathrm{E}\right)$, a tropical rural site in India. J. Geophys. Res. 107: ACH 8-1-ACH 8-13.

Noxon, J.F. (1975). Nitrogen dioxide in the stratosphere and troposphere measured by ground-based absorption spectroscopy. Science 189: 547-549.

Ojha, N., Naja, M., Singh, K. P., Sarangi, T., Kumar, R., Lal, S., Lawrence, M.G., Butler, T.M. and Chandola, H.C. (2012). Variabilities in ozone at a semi-urban site in the Indo-Gangetic Plain region: Association with the meteorology and regional processes. J. Geophys. Res. 117: D20301.

Palmer, P.I., Jacob, D.J., Chance, K., Martin, R.V., Spurr, R.J., Kurosu, T.P., Bey, I., Yantosca, R., Fiore, A. and Li, Q. (2001). Air mass factor formulation for spectroscopic measurements from satellites: Application to formaldehyde retrievals from the Global Ozone Monitoring Experiment. J. Geophys. Res. 106: 14539-14550.

Pandey, J., Agrawal, M., Khanam, N., Narayan, D. and Rao, D. (1992). Air pollutant concentrations in Varanasi, India. Atmos. Environ. 26: 91-98.

Peleg, M., Luria, M., Sharf, G., Vanger, A., Kallos, G., Kotroni, V., Lagouvardos, K. and Varinou, M. (1997).
Observational evidence of an ozone episode over the Greater Athens Area. Atmos. Environ. 31: 3969-3983.

Prados-Roman, C., Cuevas, C.A., Hay, T., Fernandez, R.P., Mahajan, A.S., Royer, S., Galí, M., Simó, R., Dachs, J., Großmann, K., Kinnison, D.E., Lamarque, J.F. and SaizLopez, A. (2015). Iodine oxide in the global marine boundary layer. Atmos. Chem. Phys. 15: 583-593.

Prasad, A.K., Singh, R.P. and Kafatos, M. (2006). Influence of coal based thermal power plants on aerosol optical properties in the Indo-Gangetic basin. Geophys. Res. Lett. 33: L05805.

Reddy, B.S., Reddy, L., Cao, J., Kumar, K.R., Balakrishnaiah, G., Gopal, K.R., Reddy, R.R., Narasimhulu, K., Lal, S. and Ahammed, Y.N. (2011). Simultaneous measurements of surface ozone at two sites over the Southern Asia: A comparative study. Aerosol Air Qual. Res. 11: 895-902.

Reddy, B.S., Kumar, K.R., Balakrishnaiah, G., Gopal, K.R., Reddy, R., Sivakumar, V., Lingaswamy, A.P., Arafath, S.M., Umadevi, K., Kumari, S.P., Ahammed, Y.N. and Lal, S. (2012). Analysis of diurnal and seasonal behavior of surface ozone and its precursors $\left(\mathrm{NO}_{\mathrm{x}}\right)$ at a semi-arid rural site in southern India. Aerosol Air Qual. Res. 12: 1081-1094.

Reddy, M. and Venkataraman, C. (2002). Inventory of aerosol and sulphur dioxide emissions from India: IFossil fuel combustion. Atmos. Environ. 36: 677-697.

Ryerson, T.B., Trainer, M., Holloway, J.S., Parrish, D.D., Huey, L.G., Sueper, D.T., Frost, G.J., Donnelly, S.G., Schauffler, S., Atlas, E.L., Kuster, W.C., Goldan, P.D., Hubler, G., Meagher, J.F. and Fehsenfeld, F.C. (2001). Observations of ozone formation in power plant plumes and implications for ozone control strategies. Science 292: 719-723.

Sánchez, M., Torre, B. D., García, M. and Pérez, I. (2005). Ozone concentrations at a high altitude station in the Central Massif (Spain). Chemosphere 60: 576-584.

Schroeder, J.R., Crawford, J.H., Fried, A., Walega, J., Weinheimer, A., Wisthaler, A., Müller, M, Mikoviny, T., Chen, G., Shook, M., Blake, D.R. and Tonnesen, G.S. (2017). New insights into the column $\mathrm{CH}_{2} \mathrm{O} / \mathrm{NO}_{2}$ ratio as an indicator of near-surface ozone sensitivity. $J$. Geophys. Res. 122: 8885-8907.

Seco, R., Peñuelas, J. and Filella, I. (2007). Short-chain oxygenated VOCs: Emission and uptake by plants and atmospheric sources, sinks, and concentrations. Atmos. Environ. 41: 2477-2499.

Sharma, S., Datta, A., Saud, T., Saxena, M., Mandal, T., Ahammed, Y. and Arya, B. (2010). Seasonal variability of ambient $\mathrm{NH}_{3}, \mathrm{NO}, \mathrm{NO}_{2}$ and $\mathrm{SO}_{2}$ over Delhi. $J$. Environ. Sci. 22: 1023-1028.

Sillman, S. and Samson, P.J. (1995). Impact of temperature on oxidant photochemistry in urban, polluted rural and remote environments. J. Geophys. Res. 100: 1149711508 .

Sinreich, R., Coburn, S., Dix, B. and Volkamer, R. (2010). Ship-based detection of glyoxal over the remote tropical Pacific Ocean. Atmos. Chem. Phys. 10: 11359-11371.

Smedt, I.D., Müller, J.F., Stavrakou, T., van der, A.R., Eskes, H. and Roozendael, M.V. (2008). Twelve years 
of global observations of formaldehyde in the troposphere using GOME and SCIAMACHY sensors. Atmos. Chem. Phys. 8: 4947-4963.

Smedt, I.D., Stavrakou, T., Müller, J.F., van der A, R.J. and Roozendael, M.V. (2010). Trend detection in satellite observations of formaldehyde tropospheric columns. Geophys. Res. Lett. 37: L18808.

Solomon, S., Portmann, R.W., Sanders, R.W., Daniel, J.S., Madsen, W., Bartram, B. and Dutton, E.G. (1999). On the role of nitrogen dioxide in the absorption of solar radiation. J. Geophys. Res. 104: 12047-12058.

Solomon, S., Schmeltekopf, A.L. and Sanders, R.W. (1987). On the interpretation of zenith sky absorption measurements. J. Geophys. Res. 92: 8311-8319.

Stavrakou, T., Müller, J., Bauwens, M., Smedt, I. D., Roozendael, M.V., Guenther, A., Wild, M. and Xia, X. (2014). Isoprene emissions over Asia 1979-2012: Impact of climate and land-use changes. Atmos. Chem. Phys. 14: 4587-4605.

Stavrakou, T., Müller, J., Boersma, K.F., Smedt, I.D. and van der A, R.J. (2008). Assessing the distribution and growth rates of $\mathrm{NO}_{\mathrm{x}}$ emission sources by inverting a 10year record of $\mathrm{NO}_{2}$ satellite columns. Geophys. Res. Lett. 35: L10801.

Stavrakou, T., Müller, J., Smedt, I.D., Roozendael, M.V., Werf, G.R., Giglio, L. and Guenther, A. (2009). Evaluating the performance of pyrogenic and biogenic emission inventories against one decade of space-based formaldehyde columns. Atmos. Chem. Phys. 9: 10371060.

Vrekoussis, M., Wittrock, F., Richter, A. and Burrows, J.P. (2010). GOME-2 observations of oxygenated VOCs: What can we learn from the ratio glyoxal to formaldehyde on a global scale? Atmos. Chem. Phys. 10: 10145-10160.

Wagner, T. (2002). UV-visible observations of atmospheric $\mathrm{O}_{4}$ absorptions using direct moonlight and zenithscattered sunlight for clear-sky and cloudy sky conditions. J. Geophys. Res. 107: 4424.

Wagner, T., Dix, B., Friedeburg, C.V., Frieß, U., Sanghavi,
S., Sinreich, R. and Platt, U. (2004). MAX-DOAS O measurements: A new technique to derive information on atmospheric aerosols-Principles and information content. J. Geophys. Res. 109: D22205.

Wagner, T., Ibrahim, O., Shaiganfar, R. and Platt, U. (2010). Mobile MAX-DOAS observations of tropospheric trace gases. Atmos. Meas. Tech. 3: 129-140.

Wagner, T., Beirle, S., Brauers, T., Deutschmann, T., Frieß, U., Hak, C., Halla, J.D., Heue, K.P., Junkermann, W., Li, X., Platt, U. and Pundt-Gruber, I. (2011). Inversion of tropospheric profiles of aerosol extinction and $\mathrm{HCHO}$ and $\mathrm{NO}_{2}$ mixing ratios from MAX-DOAS observations in Milano during the summer of 2003 and comparison with independent data sets. Atmos. Meas. Tech. 4: 2685-2715.

Wang, S.W., Zhang, Q., Streets, D.G., He, K.B., Martin, R.V., Lamsal, L.N., Chen, D., Lei, Y. and Lu, Z. (2012). Growth in $\mathrm{NO}_{\mathrm{x}}$ emissions from power plants in China: Bottom-up estimates and satellite observations. Atmos. Chem. Phys. 12: 4429-4447.

Wittrock, F., Richter, A., Oetjen, H., Burrows, J.P., Kanakidou, M., Myriokefalitakis, S., Volkamer, R., Beirle, S., Platt, U. and Wagner, T. (2006). Simultaneous global observations of glyoxal and formaldehyde from space. Geophys. Res. Lett. 33: L16804.

World Health Organization. (2013). Review of evidence on health aspects of air pollution - REVIHAAP Project 309.

Zyrichidou, I., Koukouli, M.E., Balis, D.S., Katragkou, E., Melas, D., Poupkou, A., Kioutsioukis, I., van der A, R., Boersma, F.K., van Roozendael, M. and Richter, A. (2009). Satellite observations and model simulations of tropospheric $\mathrm{NO}_{2}$ columns over south-eastern Europe. Atmos. Chem. Phys. 9: 6119-6134.

Received for review, December 28, 2018 Revised, March 14, 2019 Accepted, May 13, 2019 